\title{
MEDUSAE OF THE AMSTERDAM MID NORTH ATLANTIC PLANKTON EXPEDITIONS (1980-1983) WITH DESCRIPTION OF TWO NEW SPECIES*
}

\author{
by \\ J. BLEEKER \& S. VAN DER SPOEL \\ Institute of Taxonomic Zoology (Zoölogisch Museum), University of Amsterdam, \\ P.O. Box 4766, 1009 AT Amsterdam, The Netherlands
}

\begin{abstract}
The medusa fauna of the mid North Atlantic Ocean between $24^{\circ}$ and $55^{\circ} \mathrm{N}$ along approximately $30^{\circ} \mathrm{W}$ is studied. Two Hydromedusae new to science, Oceania tydemani and Annatiara lempersi, are described. The differences in fauna south and north of $42^{\circ} \mathrm{N}$, and faunal borders near $50^{\circ}, 48^{\circ}, 45^{\circ}, 35^{\circ}, 30^{\circ}$, and $34^{\circ}-37^{\circ} \mathrm{N}$ are discussed. The vertical distribution and for some species the diurnal migration and subtropical submergence are recorded.
\end{abstract}

\section{RÉSUMÉ}

La faune de Méduses de l'Océan Atlantique Nord central (entre $24^{\circ}$ et $55^{\circ} \mathrm{N}$; approximativement $30^{\circ} \mathrm{O}$ ) est étudiée. Deux Hydromedusae nouvelles pour la science sont décrites: Oceania tydemani et Annatiara lempersi. On discute les différences faunistiques au nord et au sud de $42^{\circ} \mathrm{N}$, ainsi que les limites faunistiques trouvées au voisinage de $50^{\circ}, 48^{\circ}, 45^{\circ}, 35^{\circ}, 30^{\circ}$, et de $34^{\circ}$ à $37^{\circ} \mathrm{N}$. Est mentionnée la distribution verticale et, pour certaines espèces, la migration diurne et la submersion subtropicale.

\section{INTRODUCTION}

Winkler (1982) described the Hydromedusae collected in spring during the Amsterdam Mid North Atlantic Plankton Expedition in 1980. Winkler \& Van Soest (1981) recorded Deepstaria enigmatica from the same cruise and Van der Spoel (1987a) listed some Coronata of the Amsterdam Mid North Atlantic Plankton Expeditions collected in the period 1980-1983.

* Amsterdam Mid North Atlantic Plankton Expeditions (AMNAPE), Project 101A. Report no. 36, supported by a grant of the Netherlands Ministry of Education and Sciences. (Report no. 35 appeared in Bulletin Zoölogisch Museum, Universiteit van Amsterdam, 11 (18): 149-152 (1988).)
The present paper gives an account of the Medusae collected by these expeditions in spring (1980), summer (1983) autumn (1981) and winter (1982); the data already published are briefly mentioned. Special attention is given to vertical distribution and faunal borders.

Some of the species are illustrated because earlier published figures are frequently diagrammatic. In some cases pictures could be prepared from colour photographs of living specimens which show the normal, not contracted, dimensions of the organism; e.g. Chromatonema rubrum (figs. 20, 21) gives a fine example of the effect of fixation and preservation.

\section{MATERIAL AND METHODS}

The material studied has been collected during four expeditions between $55^{\circ} \mathrm{N}$ and $24^{\circ} \mathrm{N}$ along approximately $30^{\circ} \mathrm{W}$ in the North Atlantic Ocean (fig. 1) during four seasons in the years 1980 (9/IV-6/V), 1981 (14/IX-14/X), 1982 (1/II-27/II) and 1983 (27/V-24/VI). During these four cruises, stations were sampled as much as possible at comparable geographic localities, but during the winter cruise in 1982 this was impossible due to bad weather conditions preventing part of the transect to be sampled.

Sampling was executed with the RMT $1+8$, a combined rectangular midwater trawl developed at the I.O.S. (Baker et al., 1973; Roe et al, 1980) in depth layers of approximately $50 \mathrm{~m}, 100 \mathrm{~m}$, and $500 \mathrm{~m}$ thick between respectively 0 and $100 \mathrm{~m}, 100$ and $500 \mathrm{~m}$, and $500 \mathrm{~m}$ and deeper. The mesh sizes of the nets were $0.32 \mathrm{~mm}$ and 4.5 $\mathrm{mm}$ so that only the relatively large species and specimens were collected. For full data on stations and environmental conditions one is referred to Van der Spoel (1981, $1985)$ and Van der Spoel \& Meerding (1983). Tempertures and salinities given in this paper are all values for the average depth of the samples.

Some species show remarkable differences in vertical distribution at day- and nighttime, but most did not. As still some vertical shifts with the time are expected, where 


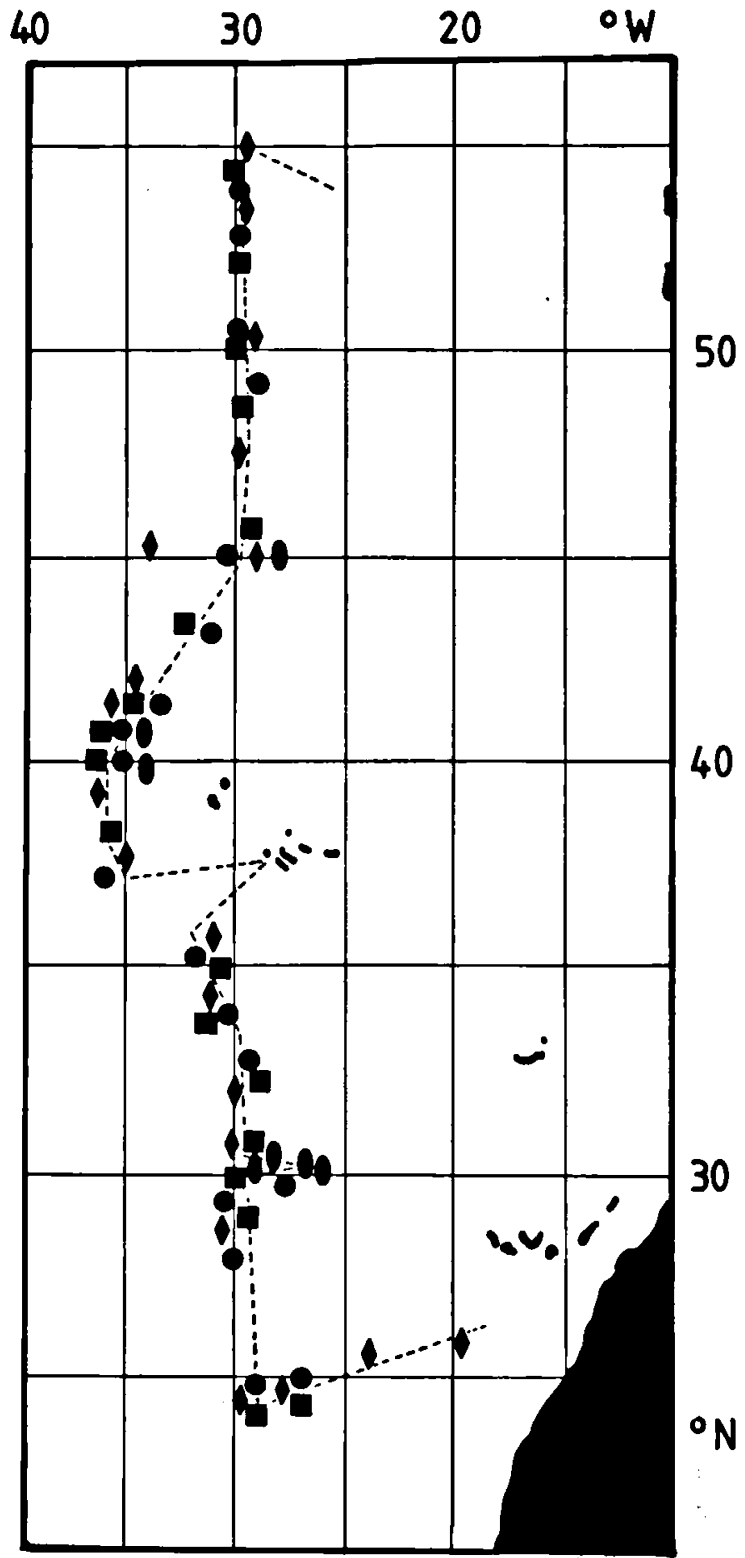

Fig. 1. Investigated area with cruise transect and indication of the position of stations; squares for 1980, diamonds for 1981, ovals for 1982 and circles for 1983.

possible vertical distribution as percentages of total catch per depth stratum, for the population at daytime and at night, is calculated for each species for all stations and it is recorded when an evident percentage of the population crosses a certain depth level between day and night.

The material studied is preserved in the Institute of Taxonomic Zoology (Zoölogisch Museum), University of Amsterdam (ZMA).

\section{RESULTS}

Of the total of 72823 specimens 232 could not be identified due to damage. The number of specimens $(=\mathbf{s p m})$ collected are given between parentheses.

\section{Class SCYPHOMEDUSAE}

(1) Deepstaria enigmatica Russell, 1967 (1 spm) was collected in spring from a 510-1090 m haul at $24^{\circ} 52^{\prime} \mathrm{N} 29^{\circ} 59^{\prime} \mathrm{W}$ (Winkler \& Van Soest, 1981).

\section{Order CORONATA}

\section{Family NAUSITHOIDAE}

(2) Nausithoe atlantica Broch, 1913 (4 spm) was found in the spring, summer and winter cruise between $55^{\circ}-30^{\circ} \mathrm{N}$ at depths between 0 and $1010 \mathrm{~m}$, temperature range 4.5$17.4^{\circ} \mathrm{C}$ (fig. 2).

(3) Nausithoe spec. (1 spm) was found during the summer cruise between $0-50 \mathrm{~m}$, at $40^{\circ} 54^{\prime} \mathrm{N}$.

(4) Nausithoe punctata Kölliker, 1853 (fig. 3) (8 spm) was found in a sample at $39^{\circ} 59^{\prime} \mathrm{N}$ in spring between 420 and $510 \mathrm{~m}$ depth and two in winter at $30^{\circ} \mathrm{N}$ between 40 and 505 $\mathrm{m}$. Temperature range $13.3-19.2^{\circ} \mathrm{C}$.

Family ATOLLIDAE

(5) Atolla wyvillei Haeckel, 1880 (171 spm) is a bathypelagic species found along the entire cruise transect (Van der Spoel, 1987a). The temperature and salinity ranges are 3$11.5^{\circ} \mathrm{C}$ and $34.42-36.21 \%$, respectively. With Atolla parva, likewise a bathypelagic species, it shares the maximum abundance at temperatures between $8^{\circ}$ and $11^{\circ} \mathrm{C}$.

(6) Atolla vanhoeffeni Russell, 1957 (304 spm) is a deep mesopelagic species living less deep than the other two relatives but showing no shallow occurrence at high latitudes, like Periphylla periphylla (cf. Van der Spoel, 1987a). The temperature and salinity ranges are $4-14.5^{\circ} \mathrm{C}$ and $34.42-36.21 \%$, respectively. The temperature curve shows two maxima for abundance, one between $8^{\circ}$ and $11^{\circ} \mathrm{C}$ and one between $12^{\circ}$ and 


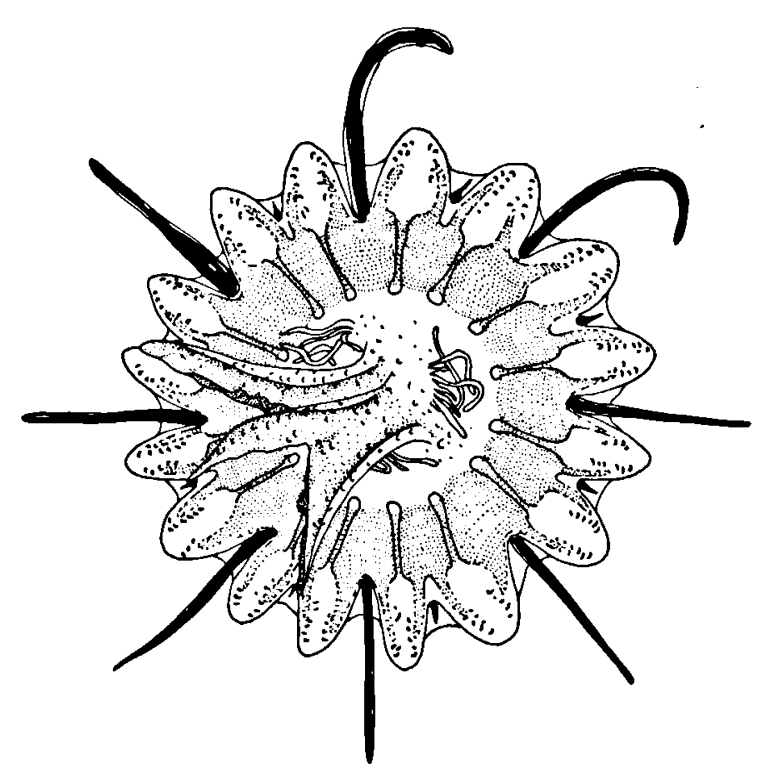

Fig. 2. Nausithoe spec. cf. atlantica from station 65 trawl 13.

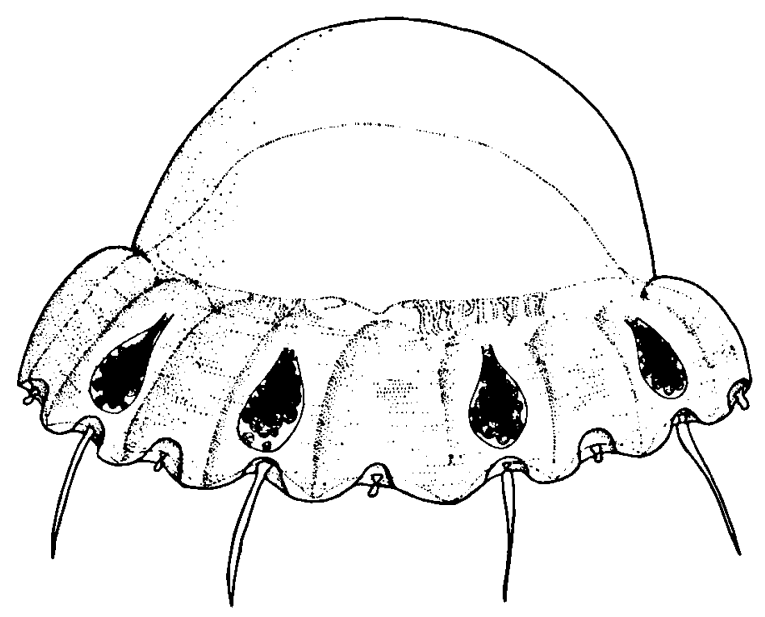

Fig. 3. Nausithoe punctata from station 68 trawl 1 .

$14^{\circ} \mathrm{C}$. This is characteristic as the two other Atolla species do not show maxima in temperature preference.

(7) Atolla parva Russell, 1958 (214 spm) is a bathypelagic species found along the entire cruise transect (Van der Spoel, 1987a). The temperature and salinity ranges are $3-13^{\circ} \mathrm{C}$ and $34.42-36.21 \%$, respectively.

Family PARAPHYLLINIDAE

(8) Paraphyllina ransoni Russell, 1936 (64 spm) was only found in summer between $54^{\circ} 20^{\prime} \mathrm{N}$ and $35^{\circ} 08^{\prime} \mathrm{N}$ at depths from 90 to $300 \mathrm{~m}$ at daytime and 100 to $1750 \mathrm{~m}$ at night. The temperature and salinity ranges are $3.5-14.3^{\circ} \mathrm{C}$ and $35.01-36.12 \%$, respectively.

Family PERIPHYLLIDAE

(9) Periphylla periphylla (Péron \& Lesueur, 1809) (1004 spm) was found in all seasons along the entire transect of the cruises as a mesopelagic species living also at shallow depth north of $42^{\circ} \mathrm{N}$ (Van der Spoel, 1987a). The temperature and salinity ranges are $3.4-19.8^{\circ} \mathrm{C}$ and $34.39-36.43 \%$, respectively. This temperature range is not reflecting real temperature preferences as the majority of the specimens is collected at temperatures between $4^{\circ}$ and $11^{\circ} \mathrm{C}$. It is notable, however, that this deep- or coldwater species is tolerating temperatures up to $19.8^{\circ} \mathrm{C}$.

\section{Order SEMAEOSTOMEAE}

Family PELAGIIDAE

(10) Pelagia noctiluca (Forskål, 1775) (fig. 4) (1739 spm) was not found in spring but occurs in high numbers in autumn, while regularly specimens were collected in sum-

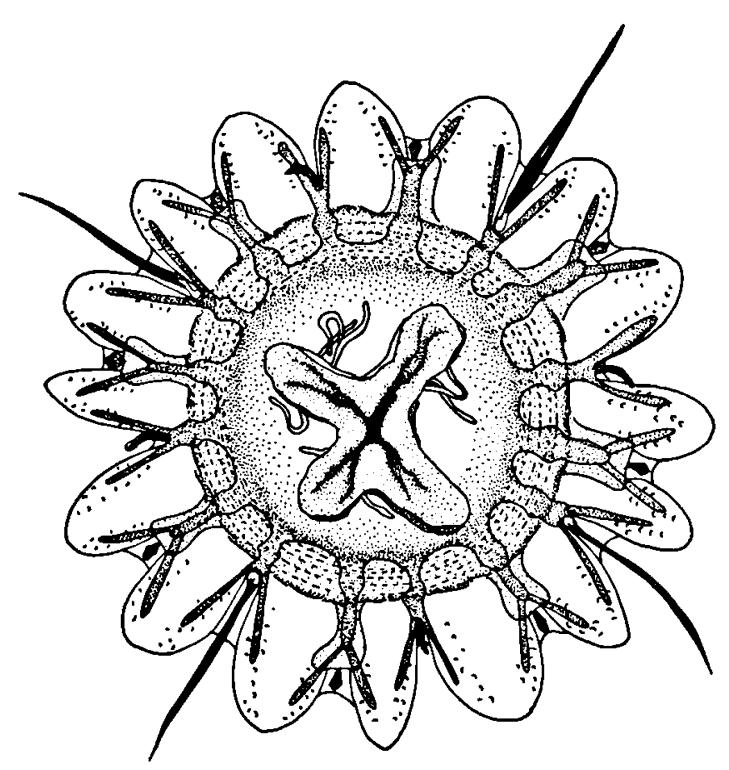

Fig. 4. Pelagia noctiluca from station 81 trawl 6 , a young specimen. 
mer and winter. It is an epipelagic species with its highest abundance in autumn between 200 and $300 \mathrm{~m}$. Vertical migration is not evident. This typically temperate species lives in autumn between $51^{\circ} \mathrm{N}$ and $24^{\circ} \mathrm{N}$, in summer between $45^{\circ} \mathrm{N}$ and $32^{\circ} \mathrm{N}$ and in winter between $40^{\circ} \mathrm{N}$ and $30^{\circ} \mathrm{N}$. The temperature and salinity ranges are $6.5-19.4^{\circ} \mathrm{C}$ and 34.40 $36.43 \%$, respectively.

\section{Class SIPHONOPHORA}

(11) Porpita porpita (Linnaeus, 1758) (3 spm) was only found in autumn between $34^{\circ} 55^{\prime} \mathrm{N}$ and $27^{\circ} 10^{\prime} \mathrm{N}$ in a night sample in the upper $50 \mathrm{~m}$ and in a day sample from 460 to $870 \mathrm{~m}$. The temperature and salinity ranges are $10.3-22.9^{\circ} \mathrm{C}$ and 35.59 $36.97 \%$, respectively.

(12) Velella velella (Linnaeus, 1758) (5 spm) was rarely found, and as young specimens only, in spring between 375 and $500 \mathrm{~m}$ at daytime as far north as $45^{\circ} 02^{\prime} \mathrm{N}$ and in autumn in night samples between 0 and $350 \mathrm{~m}$ depth at $45^{\circ} 01^{\prime} \mathrm{N}$ at $30^{\circ} 08^{\prime} \mathrm{N}$. The temperature range is $11.9-15.4^{\circ} \mathrm{C}$.

\section{Class HYDROZOA}

Order ANTHOMEDUSAE

Family CYTAEIDAE

(13) Cytaeis tetrastyla Eschscholtz, 1829 (fig. 5) (9 spm) was found in spring at $30^{\circ} \mathrm{N}$ and in winter at $37^{\circ} 08^{\prime} \mathrm{N}-30^{\circ} 06^{\prime} \mathrm{N}$ at temperatures of $12.2-23.5^{\circ} \mathrm{C}$ and salinities of $35.61-36.51 \%$. The depth of two day samples was $40-110 \mathrm{~m}$, the night samples were from depths between 0 and $520 \mathrm{~m}$.

Family CLAVIDAE

(14) Oceania armata Kölliker, 1853 (fig. 6) (14 spm) was found in autumn between $37^{\circ} 08^{\prime} \mathrm{N}$ and $26^{\circ} 08^{\prime} \mathrm{N}$ and in summer between $37^{\circ} 00^{\prime} \mathrm{N}$ and $35^{\circ} 11^{\prime} \mathrm{N}$. There seems to be no vertical migration as the day level $(40-200 \mathrm{~m})$ was not significantly different from the night level $(30-305 \mathrm{~m})$. The temperature range is $12.5-21.1^{\circ} \mathrm{C}$ and the salinity range is $35.60-37.63 \%$.
(15) Oceania tydemani n. sp. (fig. 7) (1 spm) was found in autumn at $34^{\circ} 11.4^{\prime} \mathrm{N}$, between $60-100 \mathrm{~m}$ at a temperature of $18.7^{\circ} \mathrm{C}$.

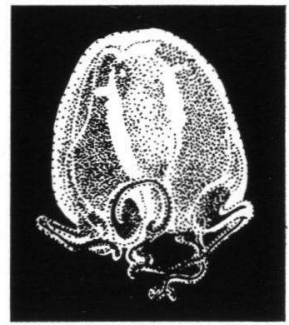

Fig. 5. Cytaeis tetrastyla from station 66 trawl 9.

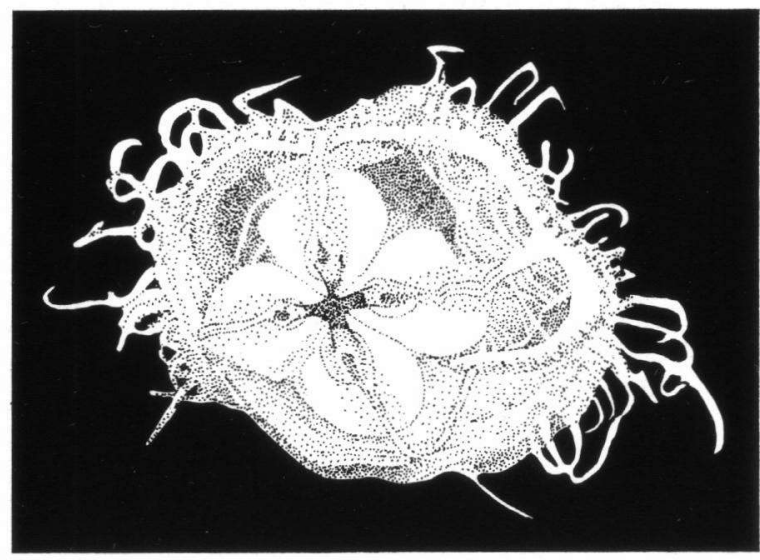

Fig. 6. Oceania armata (after colour photograph) from station 83 trawl 9.

Family BOUGAINVILLIIDAE

(16) Bougainvillia platygaster (Haeckel, 1879) (fig. 8) (78 spm) is a warm water species not found north of $30^{\circ} \mathrm{N}$ (fig. 9) and in winter restricted to $30^{\circ} \mathrm{N}$ in the cruise transect, though it is known to occur from $45^{\circ} \mathrm{S}$ to $40^{\circ} \mathrm{N}$ in the Atlantic Ocean. In summer it was not collected. This species occurred also in deeper hauls at night (500-1000 m) while at daytime it was only collected shallower than $200 \mathrm{~m}$. Normal diurnal vertical migration seems present as at night the species lives also in the upper $25 \mathrm{~m}$, while it is absent above $40 \mathrm{~m}$ at daytime, and $16 \%$ of the population crosses daily the $100 \mathrm{~m}$ level. The temperature range is $10.5-25.1^{\circ} \mathrm{C}$, the 

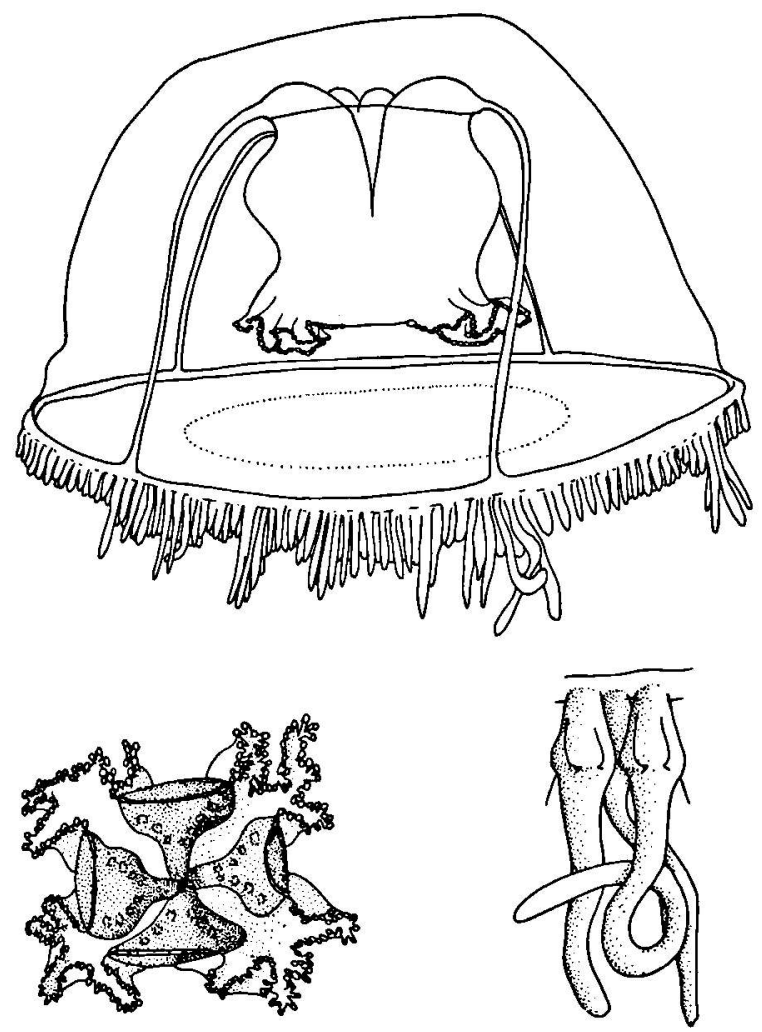

Fig. 7. Oceania tydemani n. sp. from station 48 trawl 13: animal from lateral, mouth with stomach in detail, and tentacles.

salinity range is $35.87-37.93 \%$. The symbiotic occurrence of the medusa Pegantha trilobata reported by Winkler (1982) for the spring cruise is also found in the autumn material.

Family PANDEIDAE

(17) Annatiara affinis (Hartlaub, 1913) (figs. 10, 11) (40 spm), a species mainly occurring in the East Atlantic (fig. 12), was collected in all seasons in Sargasso Sea and North Atlantic Drift waters. Though the day and night vertical ranges $85-1000 \mathrm{~m}$ do not differ, $11 \%$ of the population migrates upwards through the $300 \mathrm{~m}$ level from day to night. The temperature range is 7.8$17.0^{\circ} \mathrm{C}$, the salinity range is 35.28 $36.45 \%$.

(18) Annatiara lempersi n. sp. (fig. 13): the single specimen was collected in summer at

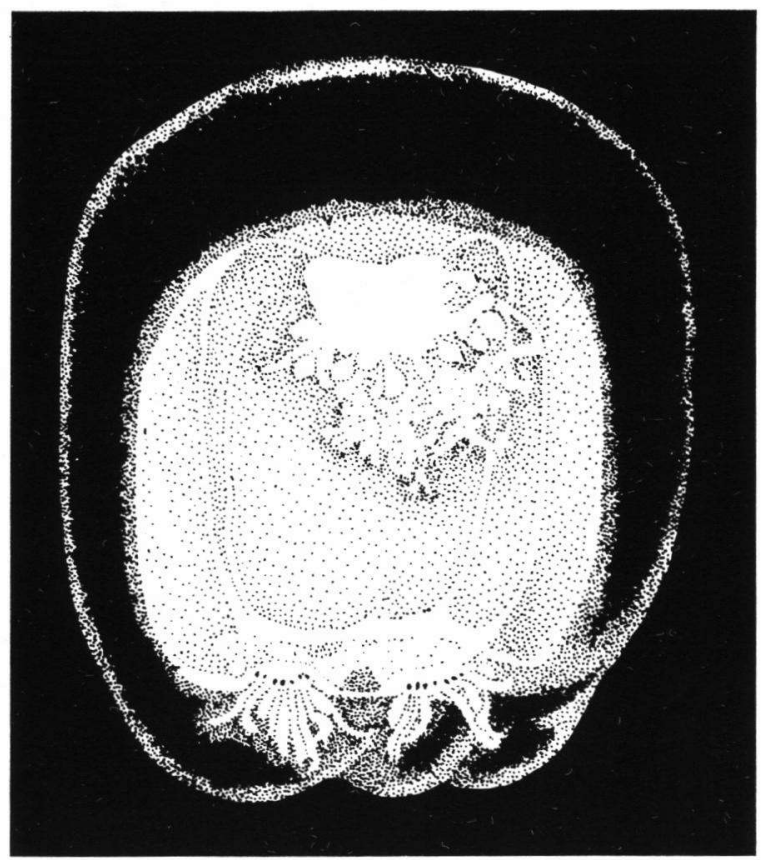

Fig. 8. Bougainvillia platygaster from station 53 trawl 9.

$31^{\circ} 30.9^{\prime} \mathrm{N}$ between 300 and $400 \mathrm{~m}$ at a temperature of $12.7^{\circ} \mathrm{C}$.

(19) Pandea rubra Bigelow, 1913 (fig. 14) (3 spm) is an epipelagic species (fig. 15) from the upper $300 \mathrm{~m}$ in the spring and autumn cruise, living at temperatures of 13.6$19.4^{\circ} \mathrm{C}$.

(20) Pandea conica (Quoy \& Gaimard, 1827) (29 spm). For distribution see fig. 16. It was only found in spring and autumn, at night (only one sample) the depth range was 45$95 \mathrm{~m}$, at daytime it was $50-300 \mathrm{~m}$; one specimen was collected in a haul of 300 to $400 \mathrm{~m}$ (daytime). The temperature range is $13.9-16.7^{\circ} \mathrm{C}$.

(21) Neoturris pileata (Forskål, 1775). Only two specimens were collected in spring near $35^{\circ} \mathrm{N}$ in a haul of $200-295 \mathrm{~m}$ and one of $320-530 \mathrm{~m}$ at temperatures between $12.5^{\circ}$ and $15.4^{\circ} \mathrm{C}$.

Family CALYCOPSIDAE

(22) Calycopsis gara Petersen, 1957 (fig. 17) (1 spm) was found in spring between 0 and $200 \mathrm{~m}$ at $41^{\circ} 01^{\prime} \mathrm{N}$ and at a temperature of $13.0-15.5^{\circ} \mathrm{C}$. 


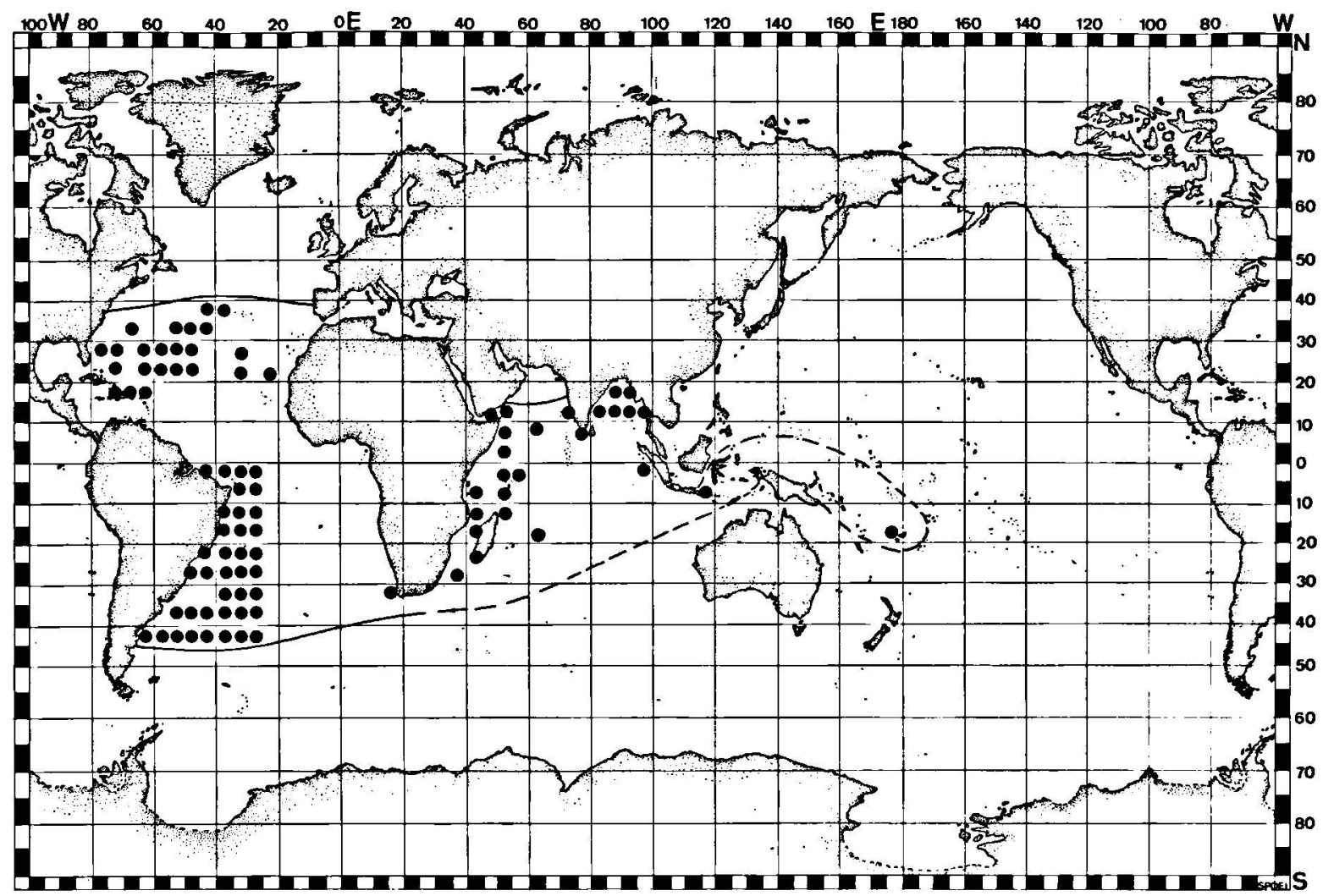

Fig. 9. Distribution of Bougainvillia platygaster.

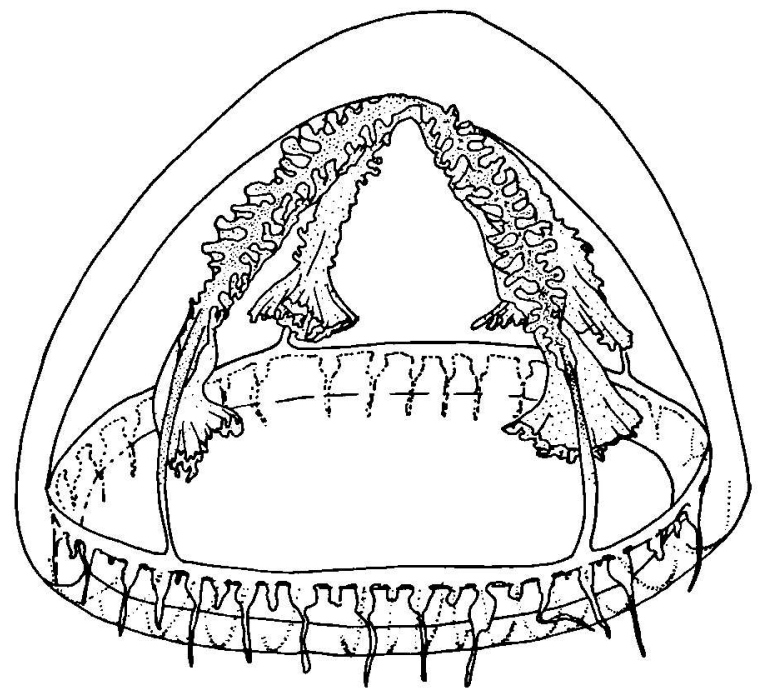

Fig. 10. Annatiara affinis from station 87 trawl $10,30 \mathrm{~mm}$ in diameter.

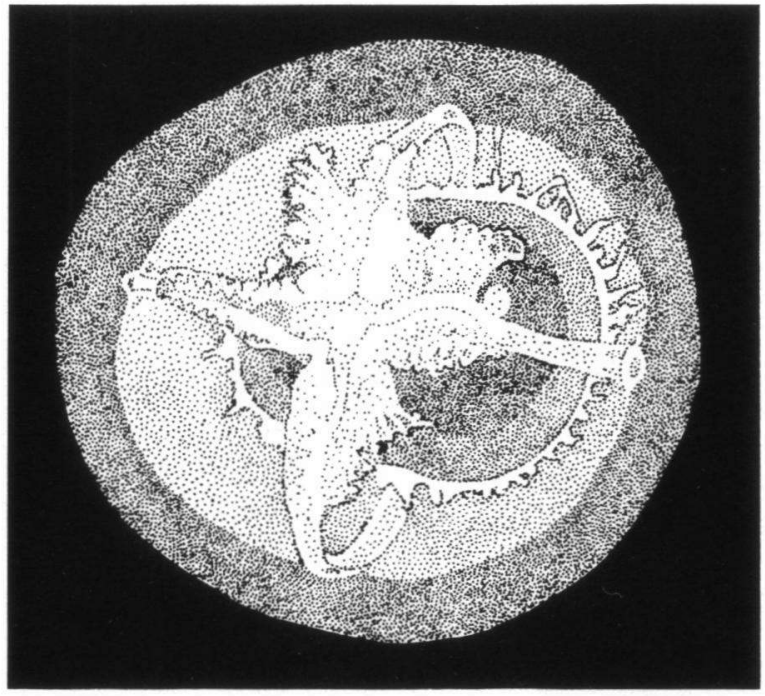

Fig. 11. Annatiara affinis (after colour photograph) from station 88 trawl 9. 


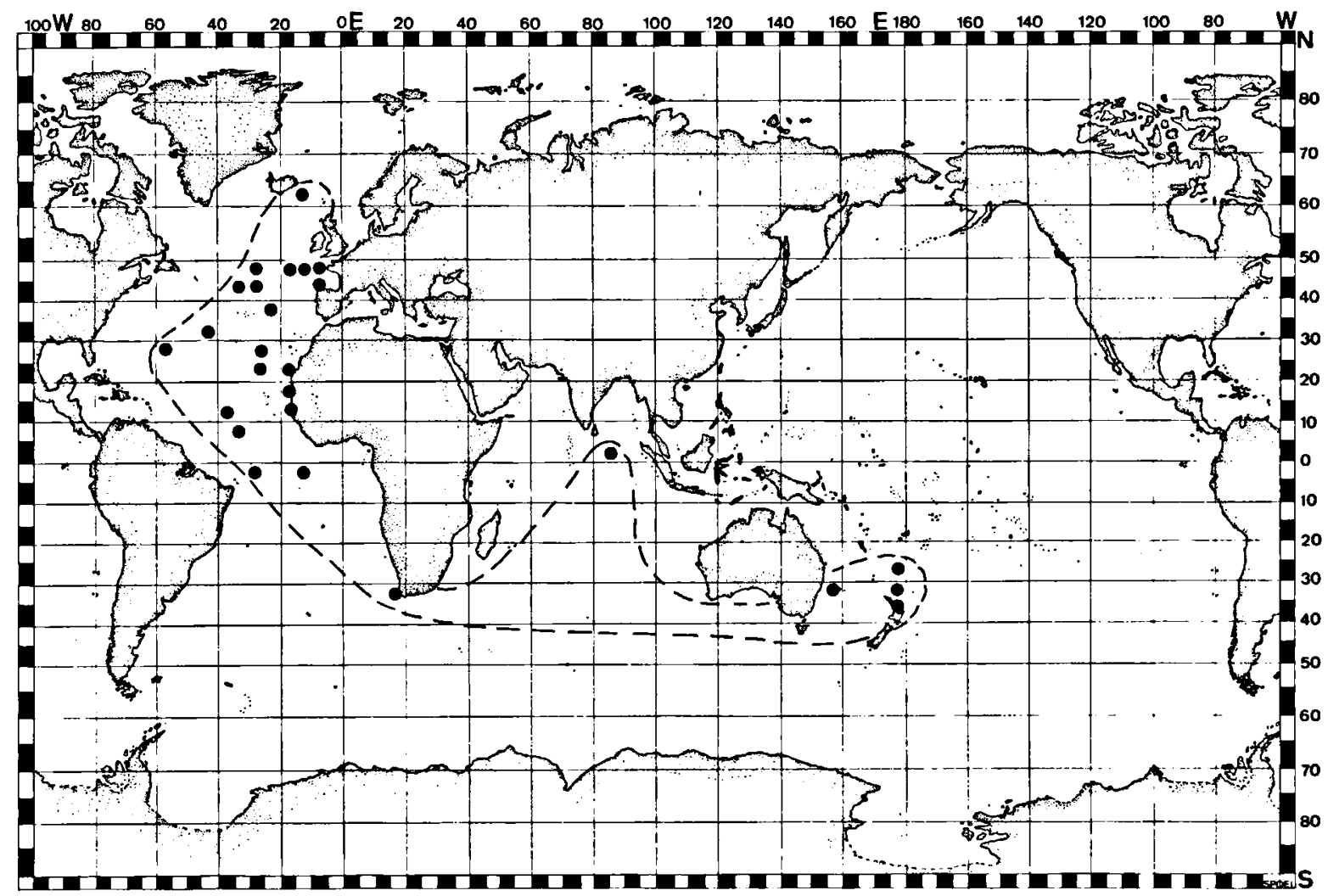

Fig. 12. Distribution of Annatiara affinis.
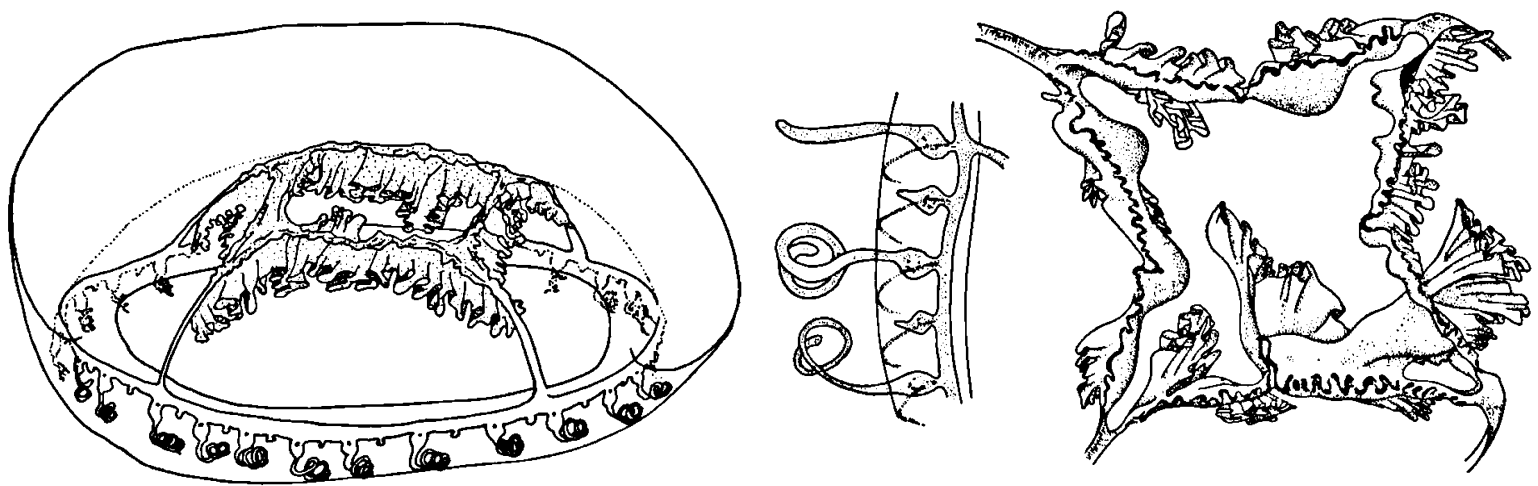

Fig. 13. Annatiara lempersi $\mathrm{n}$. sp. from station 84 trawl 36: animal from latero-apical, part of margin with tentacles, and stomach from apical. 


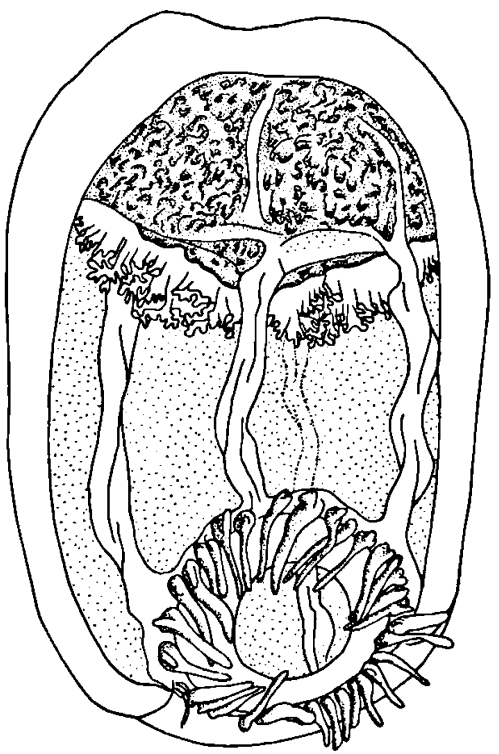

Fig. 14. Pandea rubra from station 84 trawl 35 .
(23) Bythotiara murrayi Günther, 1903 (1 spm) was found in spring at $49^{\circ} 00^{\prime} \mathrm{N}$ between 375 and $500 \mathrm{~m}$ at a temperature of $9.3^{\circ} \mathrm{C}$.

(24) Sibogita geometrica Maas, 1905 (figs. 18, 19) (6 spm) was found in spring, summer and autumn at $24^{\circ} 44^{\prime} \mathrm{N}$, between $44^{\circ} 59^{\prime}$ and $33^{\circ} 28^{\prime} \mathrm{N}$ and between $41^{\circ} 39^{\prime} \mathrm{N}$ and $35^{\circ} 07^{\prime} \mathrm{N}$, respectively. Vertical migration is evident as all night samples were taken above and all day samples below $200 \mathrm{~m}$. The temperature range is $12.9-16.4^{\circ} \mathrm{C}$ and the salinity range is $35.85-26.27 \%$.

Family TIARANNIDAE

(25) Chromatonema rubrum Fewkes, 1882 (figs. $20,21)(49 \mathrm{spm})$ is a deep living species (fig. 22) occurring between 400 and 1750 $\mathrm{m}$; probably there is some vertical migration but night samples were too few to

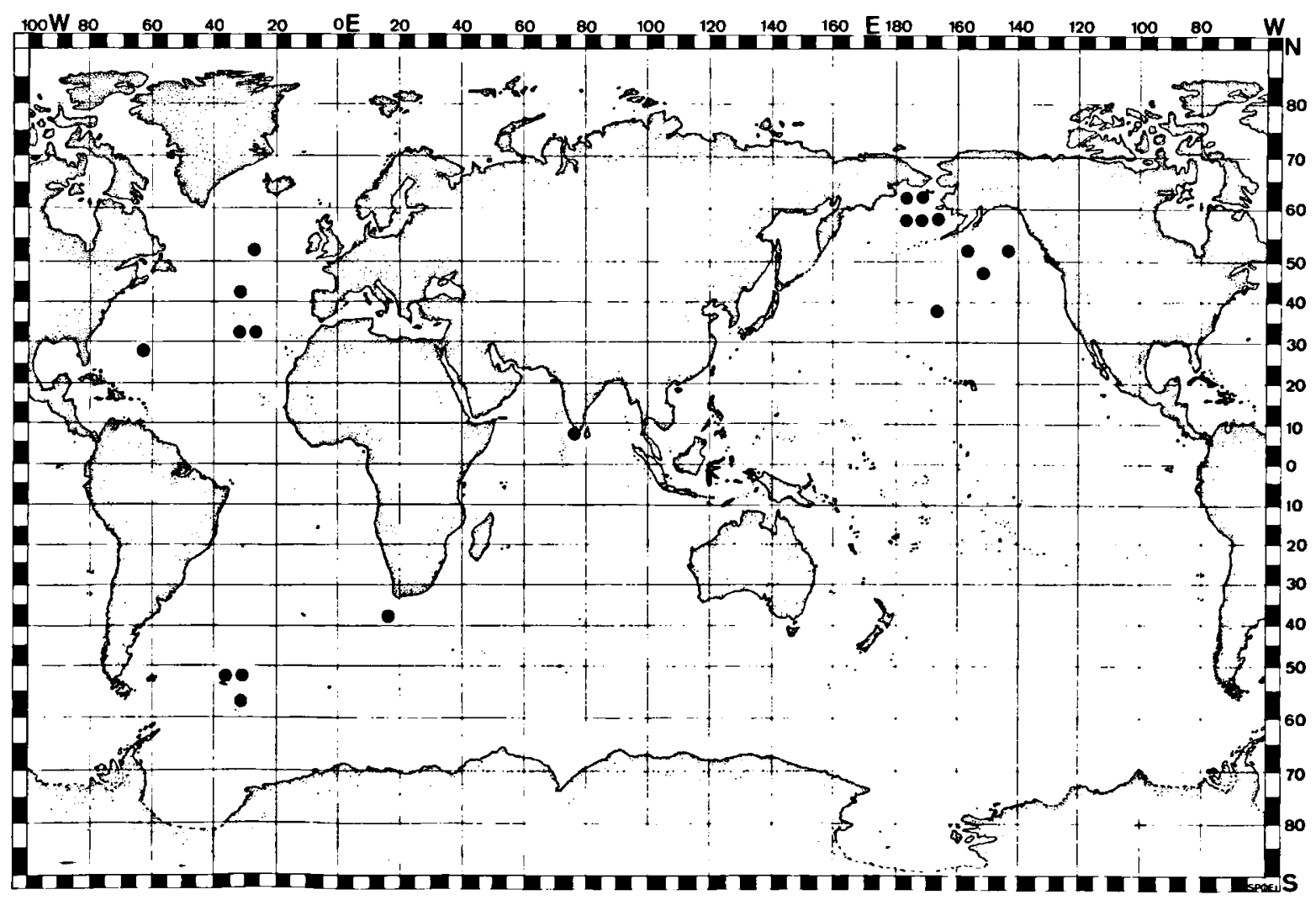

Fig. 15. Distribution of Pandea rubra. 


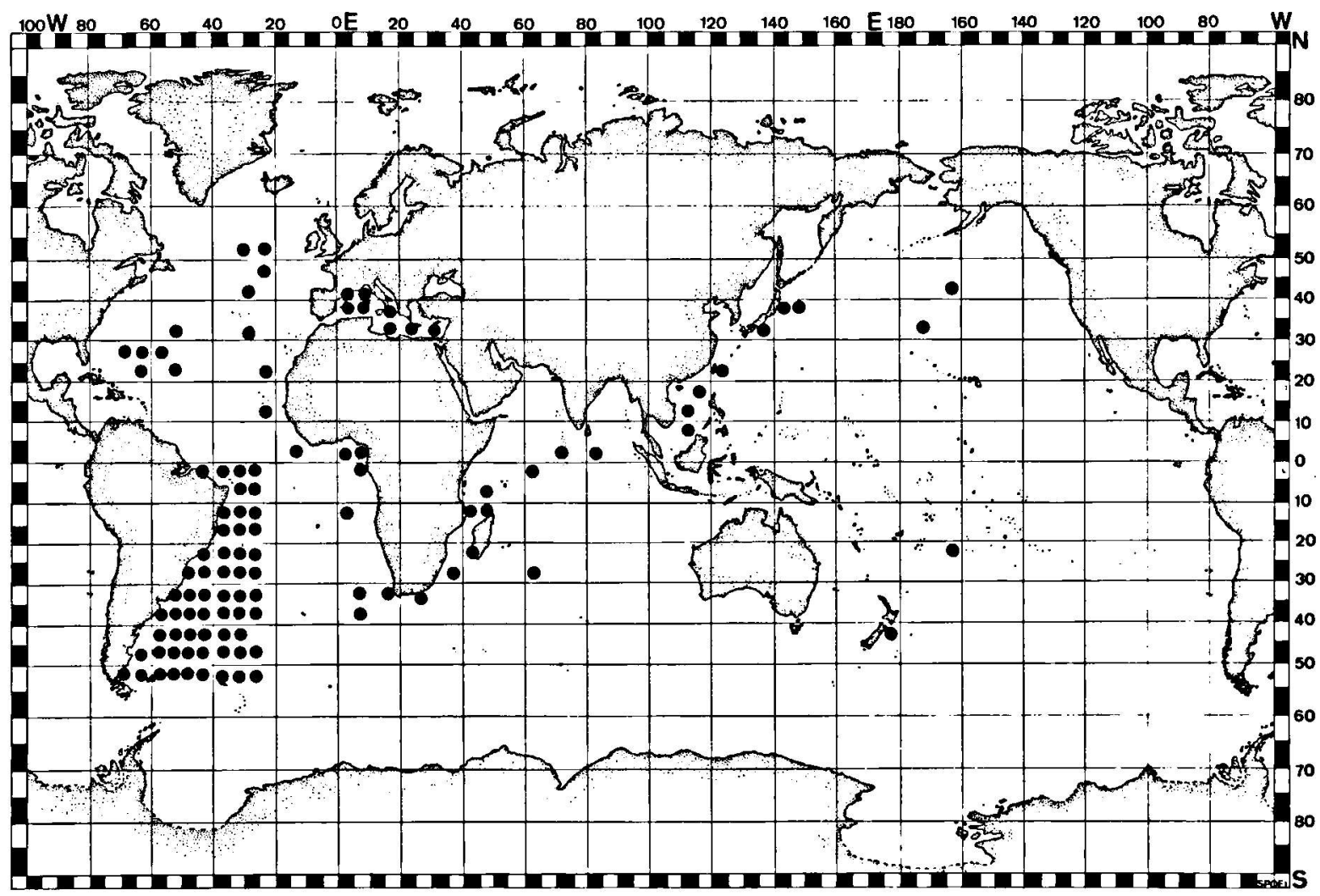

Fig. 16. Distribution of Pandea conica.

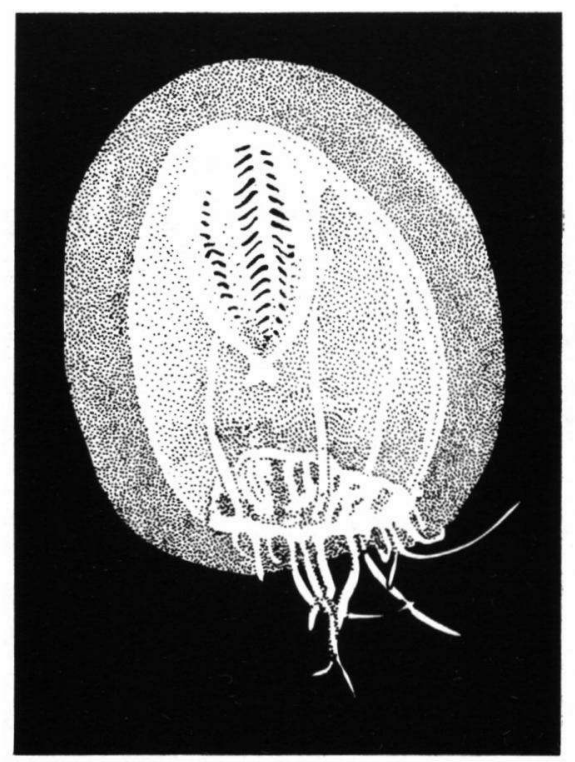

Fig. 17. Calycopsis gara from station 16 trawl 1.

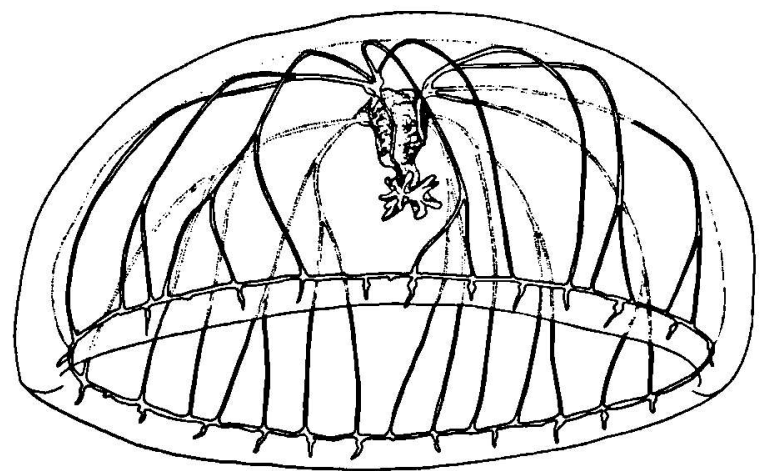

Fig. 18. Sibogila geometrica from station 85 trawl 12 . 


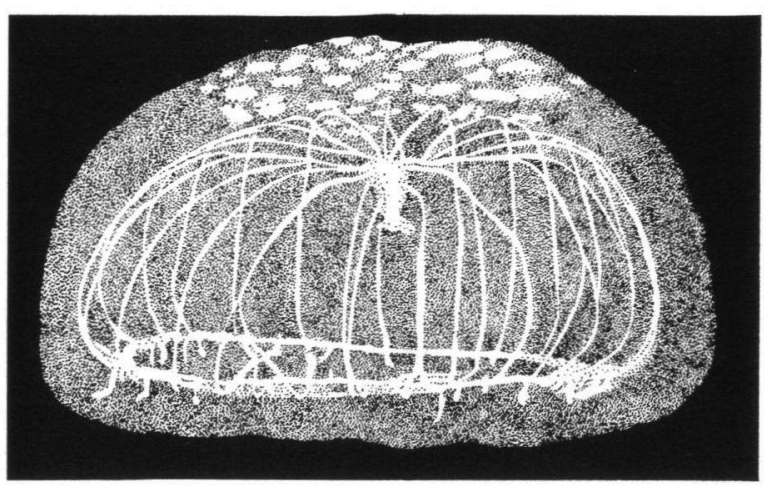

Fig. 19. Sibogita geometrica (after colour photograph) from station 47 trawl 7.

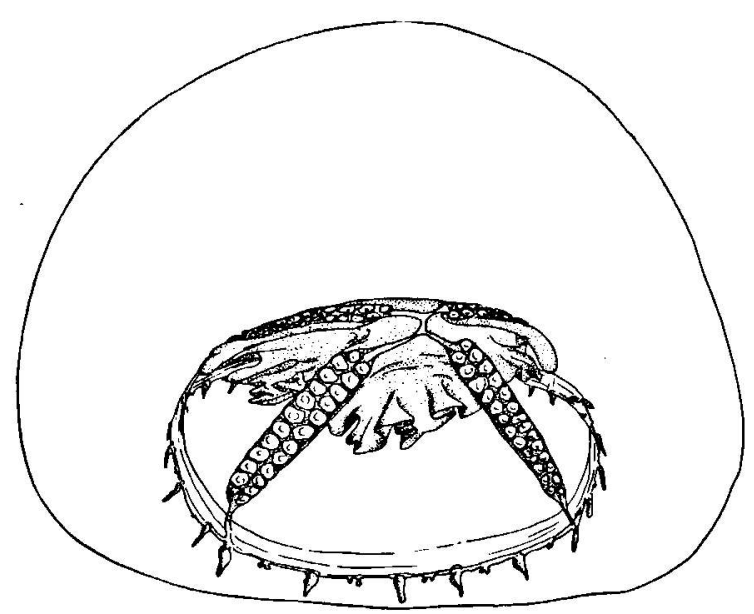

Fig. 20. Chromatonema rubrum from station 76 trawl 26.

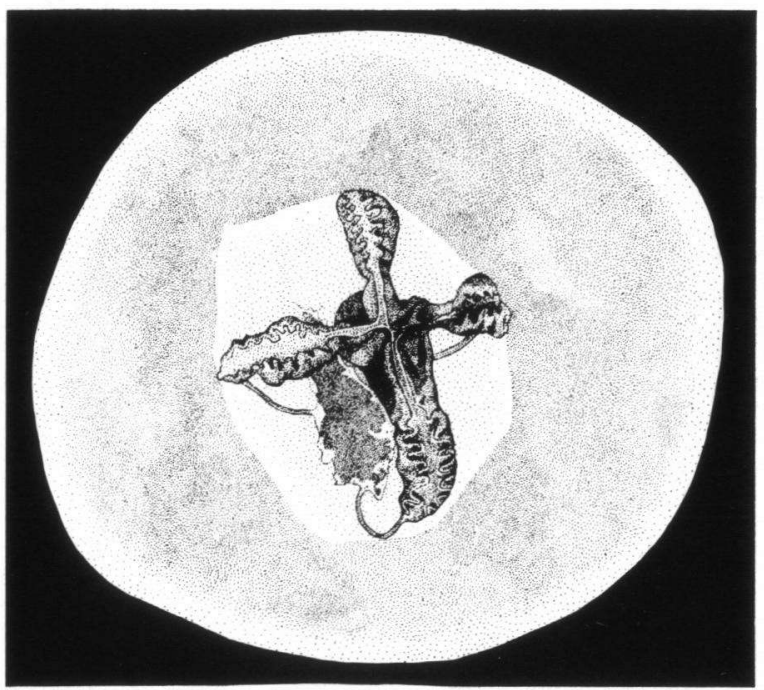

Fig. 21. Chromatonema rubrum (after colour photograph) from station 39 trawl 14. draw conclusions. The seasonal influence on this species is clear as it retracts during summer to the north and to greater depths. It occurs in spring between $55^{\circ} \mathrm{N}$ and $39^{\circ} \mathrm{N}$, during summer between $55^{\circ} \mathrm{N}$ and $48^{\circ} \mathrm{N}$ and during autumn between $55^{\circ} \mathrm{N}$ and $45^{\circ} \mathrm{N}$; in winter it is absent. The temperature range is $3.45-10.40^{\circ} \mathrm{C}$ and the salinity range is $34.96-35.41 \%$. Comparison of a preserved (fig. 20) and living specimen (fig. 21) learns that fixation causes $26 \%$ more shrinking of the jelly than of the manubrium.

\section{Order LEPTOMEDUSAE}

Family DIPLEUROSOMIDAE

(26) Cuvieria huxleyi (Haeckel, 1879) (1 spm) was found in summer between 45 and $100 \mathrm{~m}$ depth at $35^{\circ} 11^{\prime} \mathrm{N}$, temperature $16.9^{\circ} \mathrm{C}$, salinity $36.29 \%$.

Family MITROCOMIDAE

(27) Cosmetira pilosella Forbes, 1848 (12 spm) was collected between 50 and $110 \mathrm{~m}$ and 440 and $910 \mathrm{~m}$ depth at daytime in spring, at temperatures of $10.4-16.4^{\circ} \mathrm{C}$.

Family EIRENIDAE

(28) Phialopsis diegensis Torrey, 1909 (1 spm) was collected in winter at $30^{\circ} 02^{\prime} \mathrm{N}$ between 40 and $115 \mathrm{~m}$, temperature $19.2^{\circ} \mathrm{C}$.

Family EUTIMIDAE

(29) Tima flavilabris Eschscholtz, 1829 (252 spm) was only found in spring between $49^{\circ} \mathrm{N}$ and $24^{\circ} \mathrm{N}$ in the upper $500 \mathrm{~m}$ with the highest concentrations between 0 and $300 \mathrm{~m}$. Vertical migration is found as $80 \%$ of the population daily crosses the $100 \mathrm{~m}$ depth level. The temperature range is 7.8-19.5 $5^{\circ} \mathrm{C}$.

Family AEQUOREIDAE

(30) Zygocanna vagans Bigelow, 1912 (fig. 23) (2 spm) is an epipelagic species collected in the upper $300 \mathrm{~m}$ at temperatures of 14$17^{\circ} \mathrm{C}$. The Dana Expeditions collected the species at $41^{\circ} 55^{\prime} \mathrm{N} 32^{\circ} 22^{\prime} \mathrm{W}$ (Kramp, 1959) and in 1980 and 1983 the present material was collected from $41^{\circ} 35^{\prime} \mathrm{N}$ 


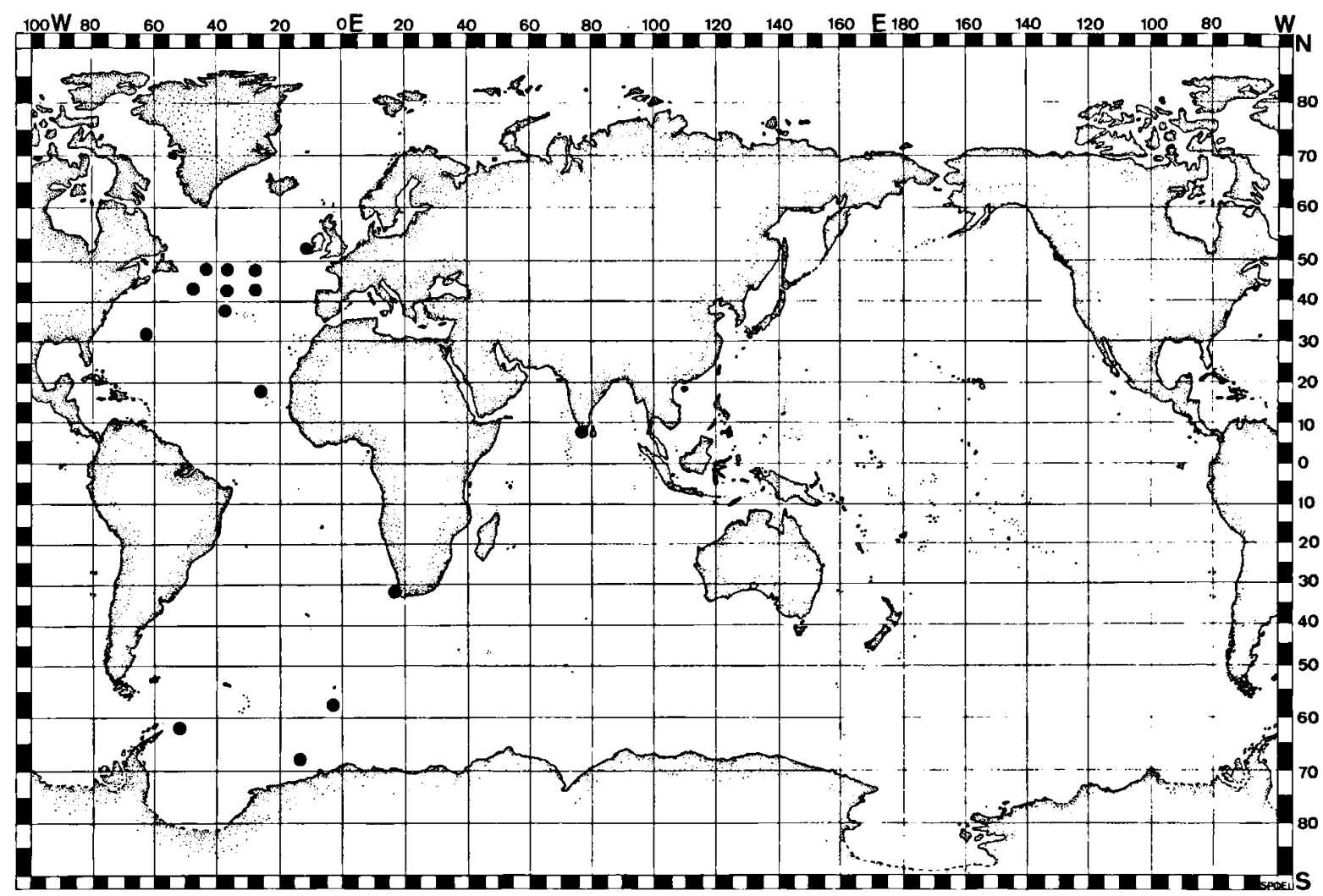

Fig. 22. Distribution of Chromatonema rubrum.

$34^{\circ} 57^{\prime} \mathrm{W}$ and $39^{\circ} 47^{\prime} \mathrm{N} \quad 35^{\circ} 32^{\prime} \mathrm{W}$, respectively, so that a very limited stable population near the Azores seems to be present. This small population is the only one hitherto recorded from the Atlantic Ocean, while numerous populations are known from the Indo-Pacific Oceans. The salinity is $36.12 \%$.

(31) Aequorea tenuis (Agassiz, 1862) was only represented by one specimen from $40^{\circ} 58^{\prime} \mathrm{N} 35^{\circ} 27^{\prime} \mathrm{W}$ between depths of 500 and $1000 \mathrm{~m}$ at a temperature of $8.5^{\circ} \mathrm{C}$.

Order TRACHYMEDUSAE

Family HALICREIDAE

(32) Halitrephes maasi Bigelow, 1909 (fig. 24) (6 spm) was only found in day samples from 440-1090 $\mathrm{m}$ depth in spring and summer between $41^{\circ} 47^{\prime} \mathrm{N}-24^{\circ} 48^{\prime} \mathrm{N}$ and at $40^{\circ} 58^{\prime} \mathrm{N}$, respectively. The temperature range is $9.8-10.5^{\circ} \mathrm{C}$.

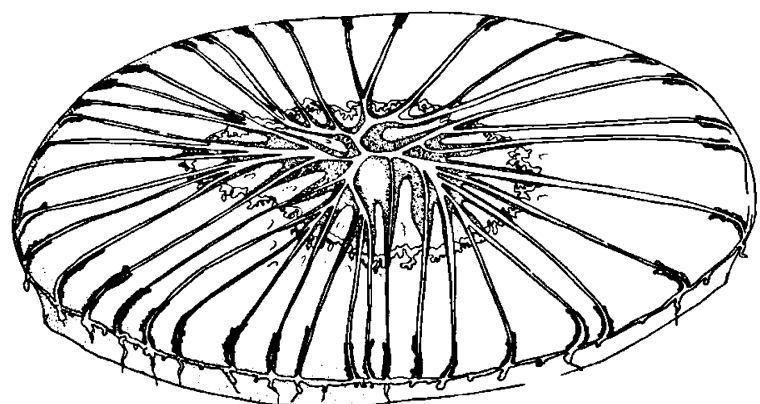

Fig. 23. Zygocanna vagans from the area around the Azores.

(33) Botrynema brucei Browne, 1908 (fig. 25) (355 spm) is a deep living species (fig. 26) found in the Atlantic between $60^{\circ} \mathrm{N}$ and $65^{\circ} \mathrm{S}$. It was found in all seasons below $480 \mathrm{~m}$, at temperatures of $3.5-9.4^{\circ} \mathrm{C}$ and salinities of $34.75-35.15 \%$. It is a high latitude species with its southern border at 


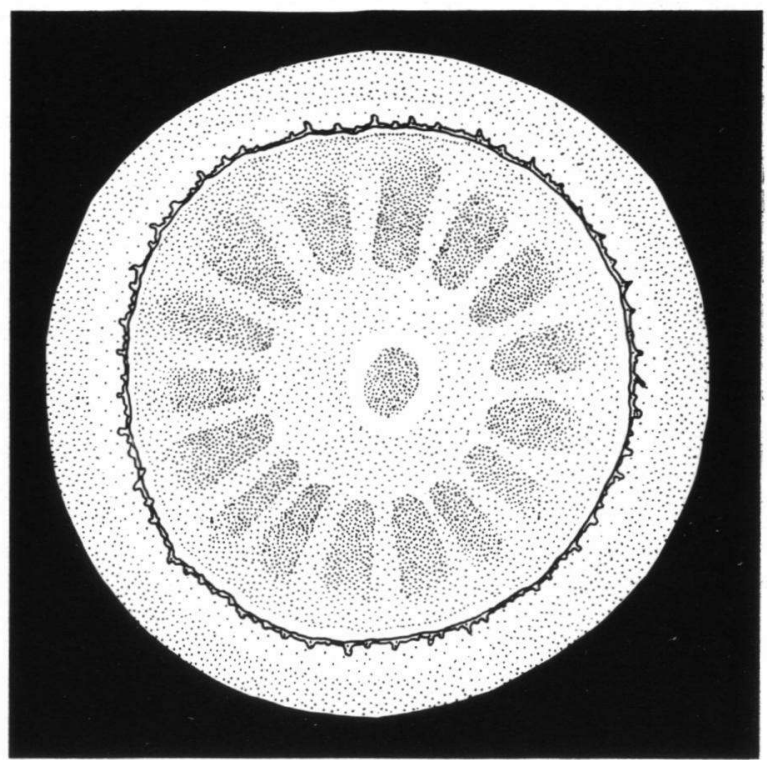

Fig. 24. Halytrephes maasi from station 81 trawl 17.

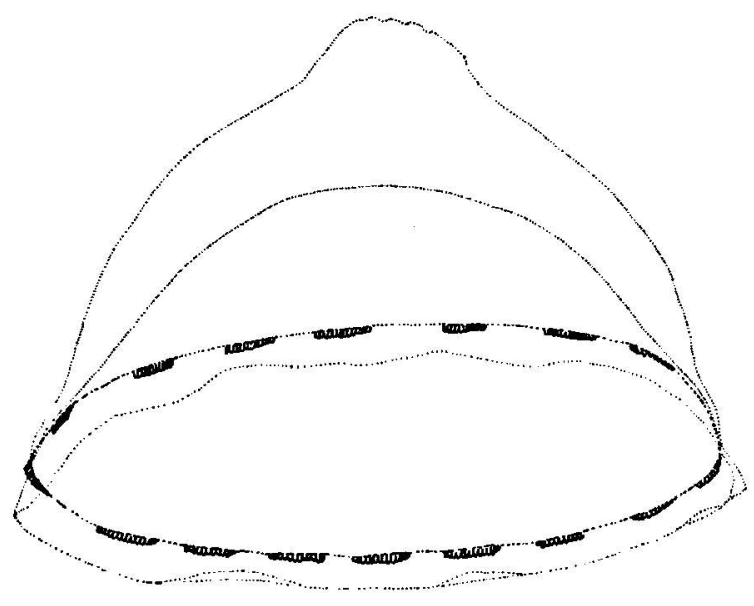

Fig. 25. Botrynema brucei from station 78 trawl 60 .

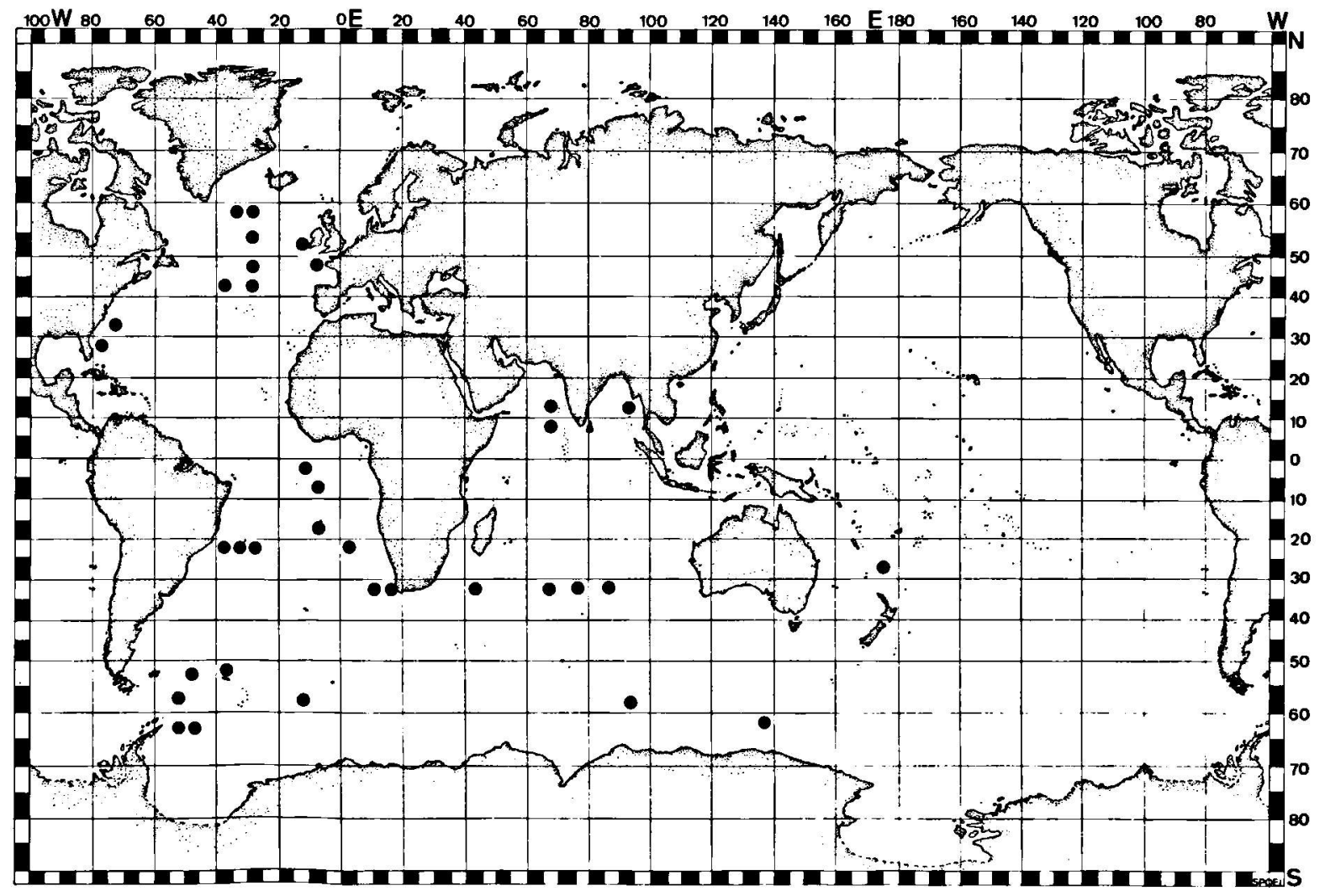

Fig. 26. Distribution of Botrynema brucei. 
$49^{\circ} \mathrm{N}$ in spring, at $45^{\circ} \mathrm{N}$ in summer, and at $40^{\circ} \mathrm{N}$ in autumn.

(34) Halicreas minimum Fewkes, 1882 (fig. 27) (547 spm). This species was found in all seasons along the entire cruise transect from $24^{\circ}$ to $55^{\circ} \mathrm{N}$ and only below a depth of $500 \mathrm{~m}$. The temperature range is $3.5-$ $11.0^{\circ} \mathrm{C}$, though highest abundances are found at temperatures below $8^{\circ} \mathrm{C}$; the salinity range is $34.75-35.87 \%$.

(35) Haliscera bigelowi Kramp, 1947 (176 spm) was found in night samples between 330 and $505 \mathrm{~m}$ and in daytime samples between 205 and $1020 \mathrm{~m}$. It occurs in spring, summer and autumn. The temperature range is $4.5-19.2^{\circ} \mathrm{C}$, most abundant between $8^{\circ}$ and $11^{\circ} \mathrm{C}$ and only sporadic at temperatures above $12^{\circ} \mathrm{C}$; the salinity range is $34.74-36.13 \%$.

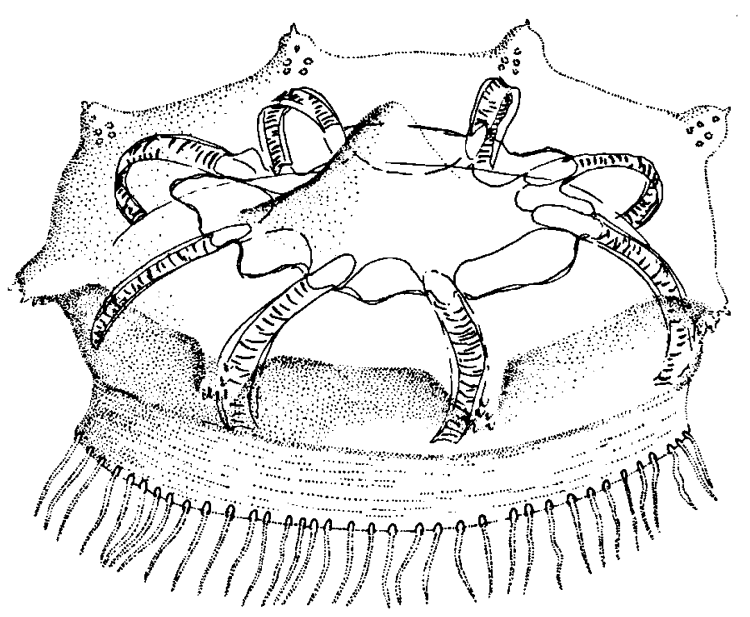

Fig. 27. Halicreas minimum from station 81 trawl 6 .

Family RHOPALONEMATIDAE

(36) Rhopalonema funerarium Vanhöffen, 1902 (27 spm) was only found in winter at $30^{\circ} 00^{\prime} \mathrm{N}$ at temperatures of $18.5-19.0^{\circ} \mathrm{C}$. Though considered to be a bathypelagic species (Kramp, 1959) it is found in a 40$115 \mathrm{~m}$ (24 specimens) haul and 395-995 m hauls ( 3 specimens).

(37) Rhopalonema velatum Gegenbaur, 1856 (fig. 28) (583 spm) occurred in all seasons

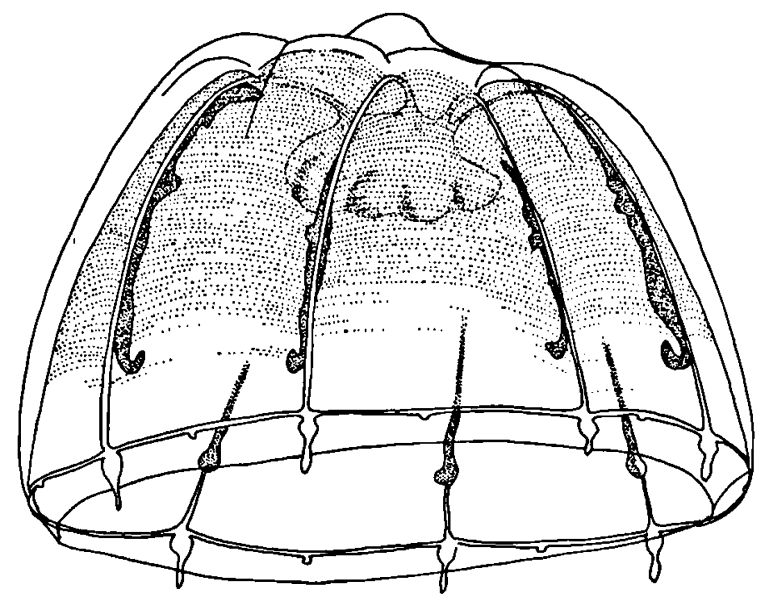

Fig. 28. Rhopalonema velatum from station 84 trawl 36 .

between 0 and $1760 \mathrm{~m}$ depth; the northern limit only changes slightly being at $49^{\circ} \mathrm{N}$ in spring, at $45^{\circ} \mathrm{N}$ in summer, at $51^{\circ} \mathrm{N}$ in autumn and probably at $30^{\circ} \mathrm{N}$ in winter (the winter cruise, however, sampled too few stations to be sure of this limit). A very slight tendency of vertical migration is found in this eurybathic species as $5 \%$ of the population crossed the $50 \mathrm{~m}$ level, $11 \%$ crossed the $100 \mathrm{~m}$ level and $2 \%$ crossed the $200 \mathrm{~m}$ level daily. The temperature and salinity ranges are 6.15$25.7^{\circ} \mathrm{C}$ (most specimens are, however, collected between $10^{\circ}$ and $20^{\circ} \mathrm{C}$ ) and 35.09-37.10\%, respectively. For general distribution see fig. 29.

(38) Crossota spec. (fig. 30) (1 spm) was found between 500 and $1000 \mathrm{~m}$ in summer, at $40^{\circ} 45^{\prime} \mathrm{N}$ and at $8.8^{\circ} \mathrm{C}$ and $35.45 \% \mathrm{~S}$.

(39) Crossota alba Bigelow, 1913 (5 spm) was found in samples between 0 and $220 \mathrm{~m}$ and between 420 and $1752 \mathrm{~m}$, but there is no indication of diurnal migration. Though the shallow sample from 0 to 220 $\mathrm{m}$ was taken by a malfunctioning discrete depth net it is excluded that the depth record is incorrect as the net was never lowered below $250 \mathrm{~m}$, so it is concluded that the species is eurybathic. It occurs in spring at $39^{\circ} 59^{\prime} \mathrm{N}$, in summer at $45^{\circ} \mathrm{N}$ and in winter between $40^{\circ} 55^{\prime} \mathrm{N}$ and 


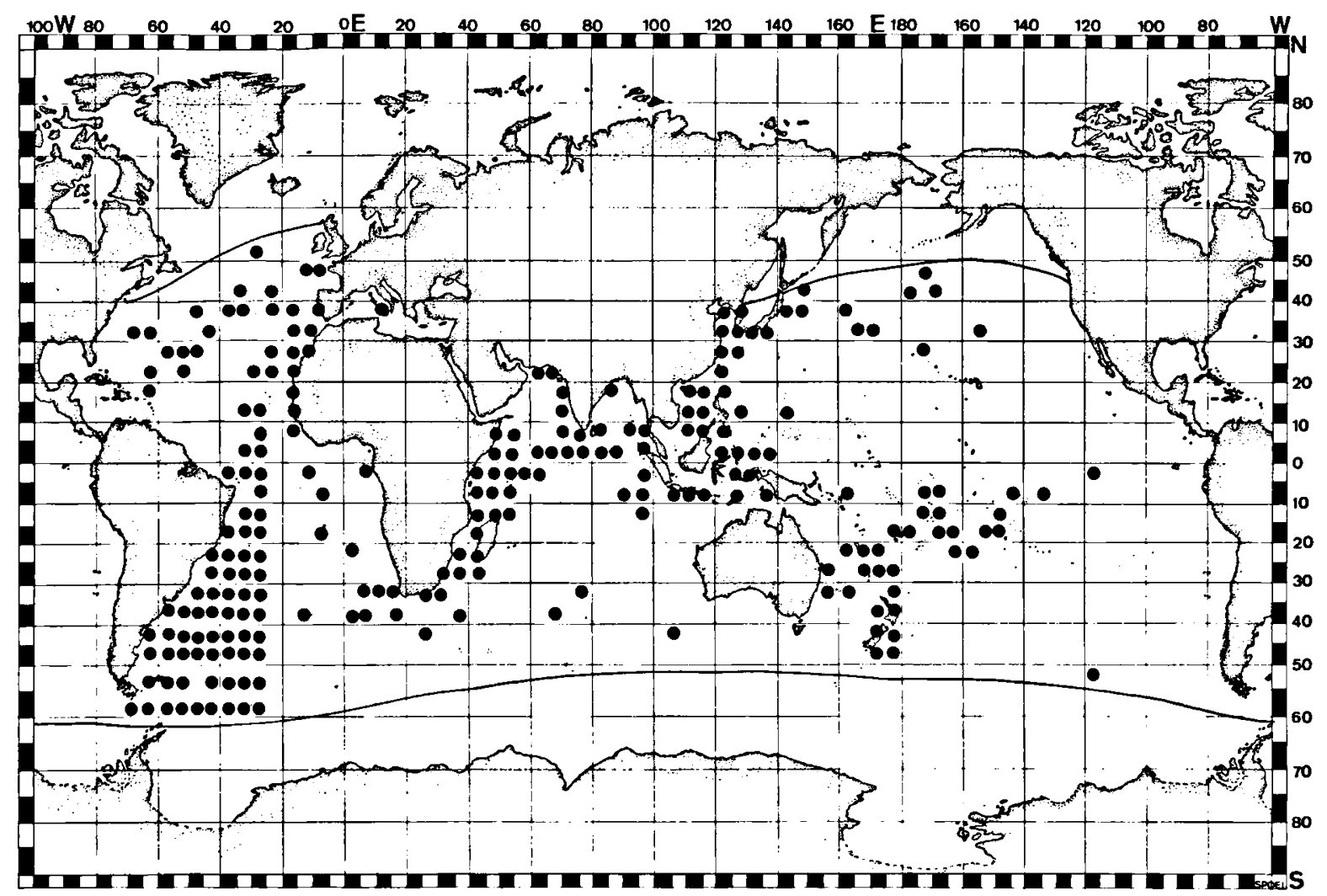

Fig. 29. Distribution of Rhopalonema velatum.

$29^{\circ} 59^{\prime} \mathrm{N}$. The temperature range is 4.4$16.0^{\circ} \mathrm{C}$ and the salinity was $35.12 \%$.

(40) Crossota rufobrunnea (Kramp, 1913) (fig. 31) (404 spm) was found in spring between $55^{\circ}$ and $40^{\circ} \mathrm{N}$, in summer between $55^{\circ}$ and $35^{\circ} \mathrm{N}$ and in autumn between $55^{\circ}$ and $48^{\circ} \mathrm{N}$. In the day samples the species occurs always below $420 \mathrm{~m}$ depth and the single night sample was from $520-1130 \mathrm{~m}$ depth (1 specimen). The temperature and salinity ranges are $4.2-9.9^{\circ} \mathrm{C}$ and 34.75 $35.55 \%$, respectively.

(41) Sminthea eurygaster Gegenbaur, 1856 (fig. 32) (13 spm) was found in summer and winter at (probably $45^{\circ} 02^{\prime}$ ) $-35^{\circ} 11^{\prime} \mathrm{N}$ and $29^{\circ} 59^{\prime}-30^{\circ} 03^{\prime} \mathrm{N}$, respectively. The temperatue and salinity ranges are 8.2$19.2^{\circ} \mathrm{C}$ and $35.41-35.75 \%$.

(42) Colobonema sericeum Vanhöffen, 1902 (fig. 33) (246 spm) was found in spring between

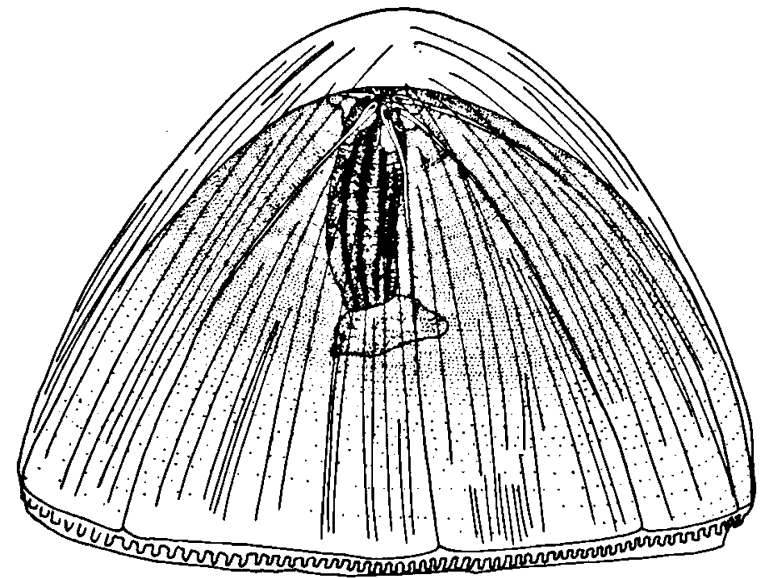

Fig. 30. Crossota spec. from station 81 trawl 6.

$55^{\circ}$ and $25^{\circ} \mathrm{N}$ and in the other seasons between $50^{\circ}$ and $25^{\circ} \mathrm{N}$ as a deep living species restricted to depths below $365 \mathrm{~m}$. 

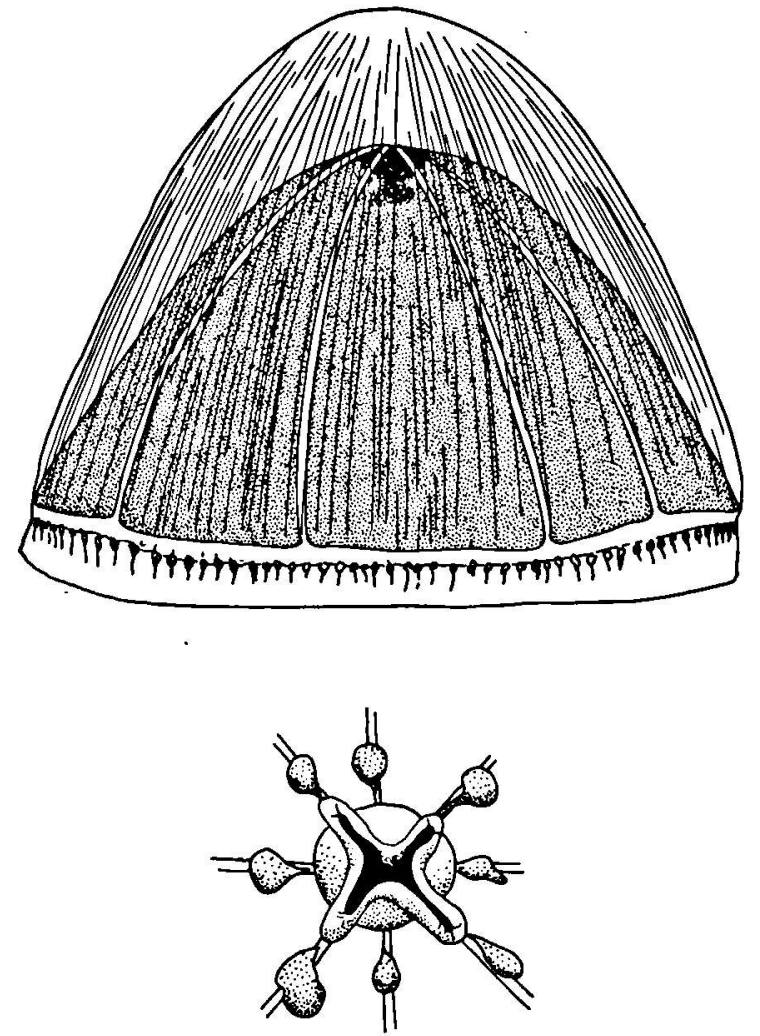

Fig. 31. Crossola rufobrunnea from station 81 trawl 6: animal from lateral and mouth and gonads from aboral.

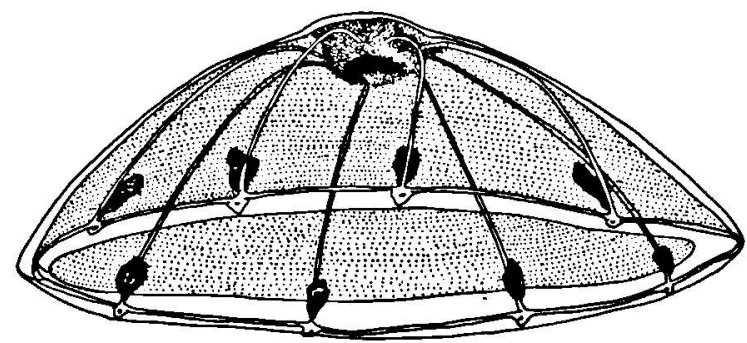

Fig. 32. Sminthea eurygaster from station 84 trawl 6.

The distribution in the Atlantic Ocean is between $60^{\circ} \mathrm{N}$ and $60^{\circ} \mathrm{S}$. The temperature and salinity ranges are $4.5-15.2^{\circ} \mathrm{C}$ and 35.09-36.70\%, respectively. The temperatures of $4.5-8.5^{\circ} \mathrm{C}$ are only recorded for daytime samples; the maxima of abundance are found at temperatures of 9$12^{\circ} \mathrm{C}$ and at $14^{\circ} \mathrm{C}$.

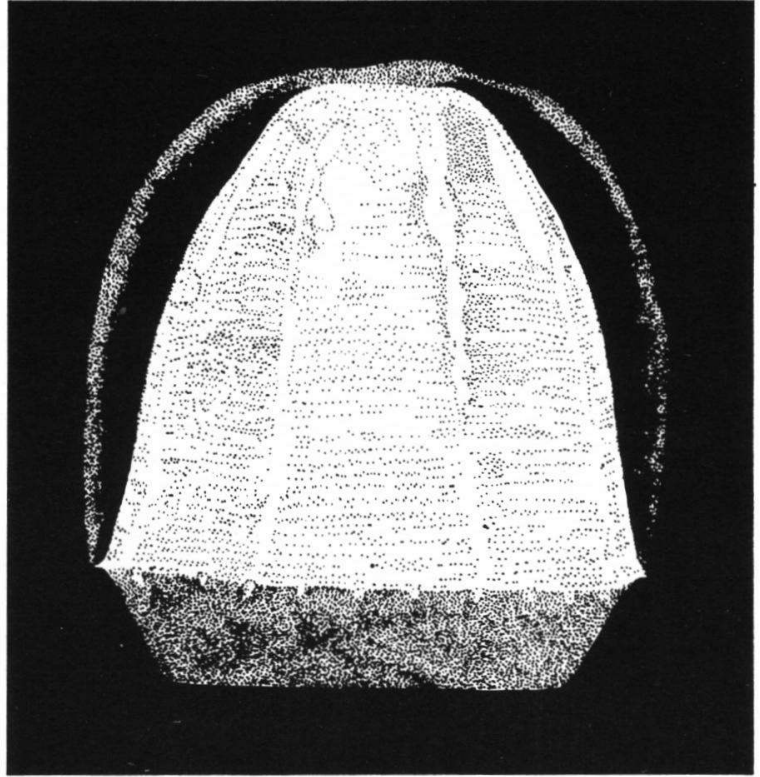

Fig. 33. Colobonema sericeum (after colour photograph) from station 84 trawl 36 .

(43) Pantachogon haeckeli Maas, 1893 (tigs. 34, 35) (1650 spm) was most abundant at greater depths. At daytime 1041 specimens were collected of which no one in hauls shallower than $870 \mathrm{~m}$. At night 21 specimens were collected of which 3 between 0 and $100 \mathrm{~m}$ and 4 between 360 and $520 \mathrm{~m}$. Thus there may exist some vertical migration. The species was found in all seasons along the whole cruise transect from $55^{\circ}$ to $24^{\circ} \mathrm{N}$. The temperature and salinity ranges are 3.5$19.2^{\circ} \mathrm{C}$ and $34.95-35.95 \%$, respectively. This is a widely distributed species in all oceans between $70^{\circ} \mathrm{N}$ and $70^{\circ} \mathrm{S}$ (fig. 36).

(44) Amphogona apsteini (Vanhöffen, 1902) (fig. 37) (6 spm) occurred in summer at $54^{\circ} 20^{\prime} \mathrm{N}$ and in autumn at $41^{\circ} 44^{\prime} \mathrm{N}$, though it is in literature mentioned as a surface form (Kramp, 1959) between depths of 460 and $1750 \mathrm{~m}$. The temperature and salinity ranges are 3.45$10.25^{\circ} \mathrm{C}$ and $35.03-35.59 \%$, respectively.

(45) Amphogona apicata Kramp, 1957 (fig. 38) (8 spm) occurred in summer between $45^{\circ} 02^{\prime}$ and $35^{\circ} 09^{\prime} \mathrm{N}$ and in winter at $29^{\circ} 59^{\prime} \mathrm{N}$ 


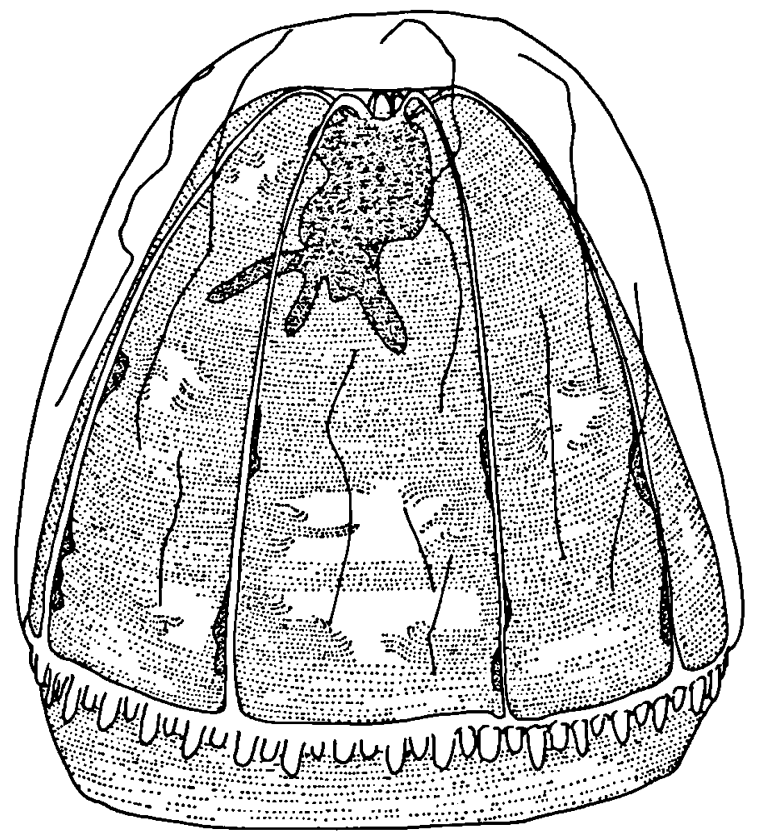

Fig. 34. Pantachogon haeckeli from station 81 trawl 17.

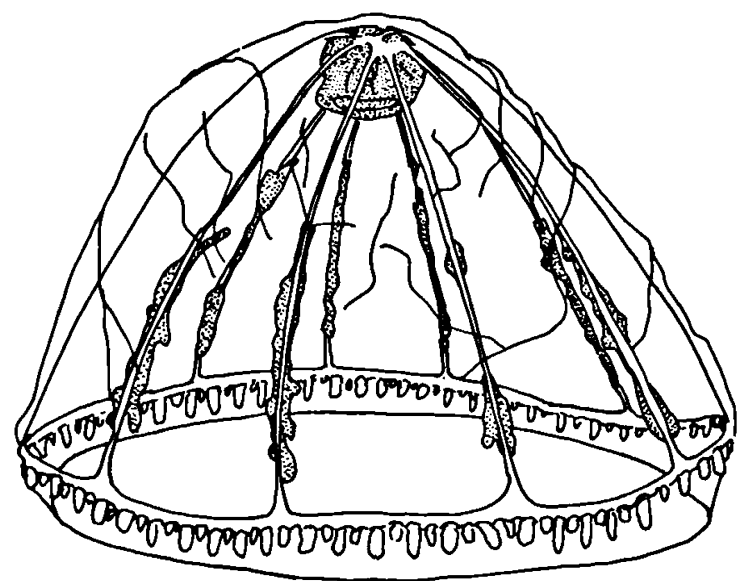

Fig. 35. Pantachogon haeckeli from station 78 trawl 60 .

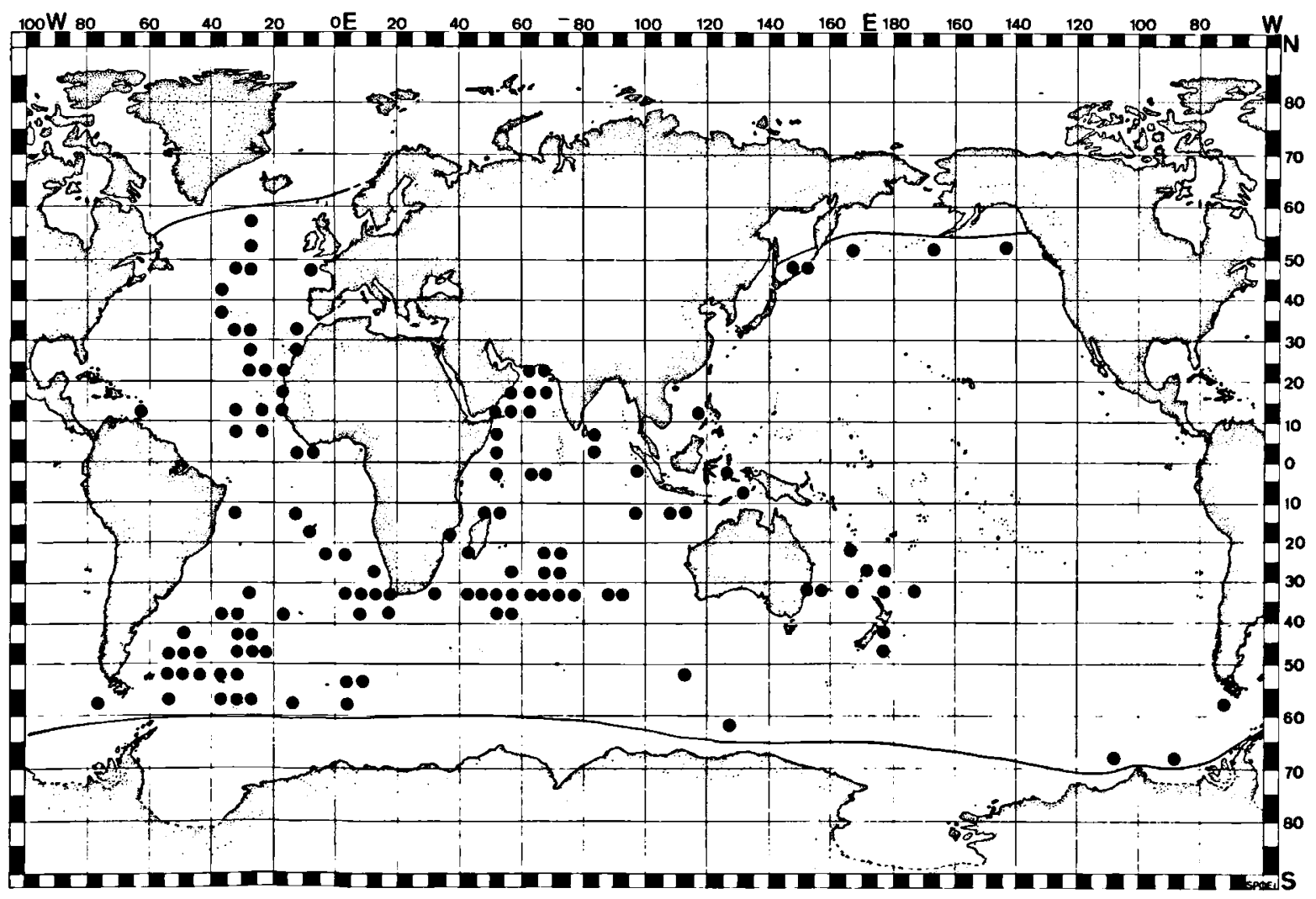

Fig. 36. Distribution of Pantachogon haeckeli. 


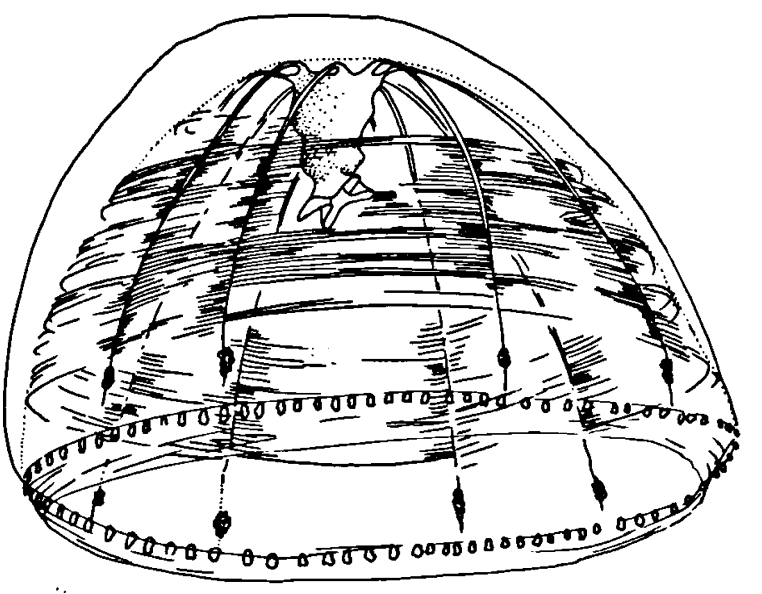

Fig. 37. Amphogona apsteini from station 78 trawl 39.

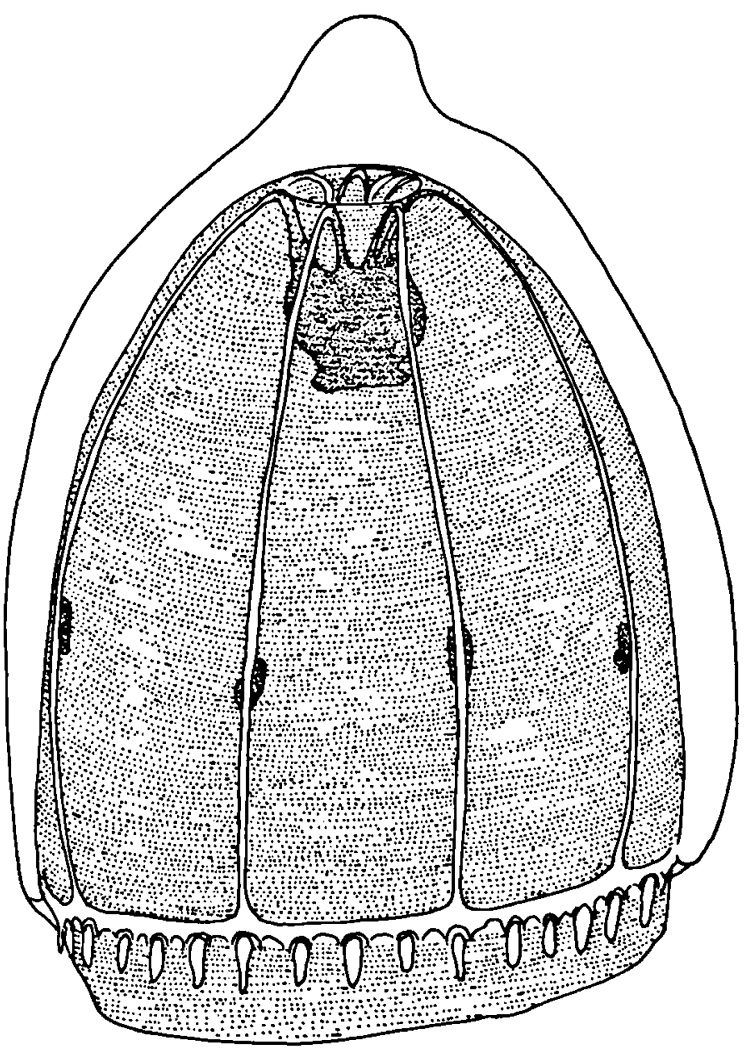

Fig. 38. Amphogona apicata from station 84 trawl 77.

always below $490 \mathrm{~m}$. The temperature and salinity ranges are $6.15-10.3^{\circ} \mathrm{C}$ and 35.41 $33.55 \%$, respectively.

(46) Tetrorchis erythrogaster Bigelow, 1909 (fig. 39 ) was only represented by one specimen

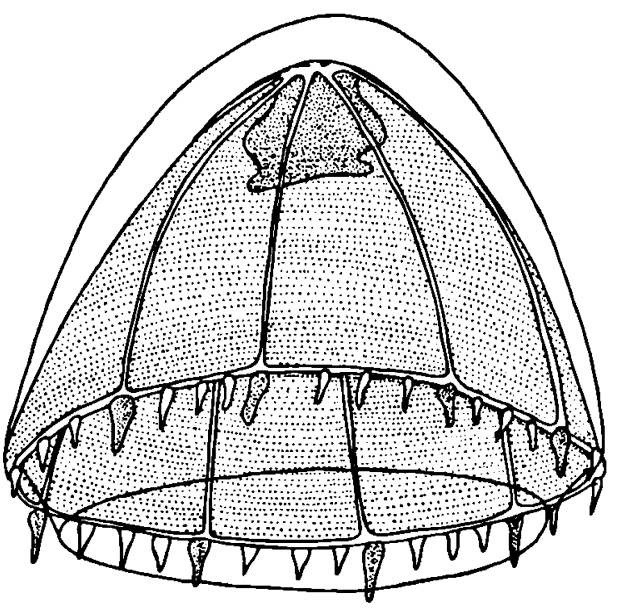

Fig. 39. Tetrorchis erythrogaster from station 78 trawl 39.

between 500 and $1000 \mathrm{~m}$, in summer at $45^{\circ} 02^{\prime} \mathrm{N}$. The temperature and salinity were $8.15^{\circ} \mathrm{C}$ and $35.41 \%$.

(47) Aglaura hemistoma Péron \& Lesueur, 1809 (21 spm) was found only in winter at $29^{\circ} 58^{\prime} \mathrm{N}$ at a depth of 0 to $150 \mathrm{~m}$.

(48) Aglantha digitale (O. F. Müller, 1766) (figs. $40,41)(61821 \mathrm{spm})$ occurred at depths

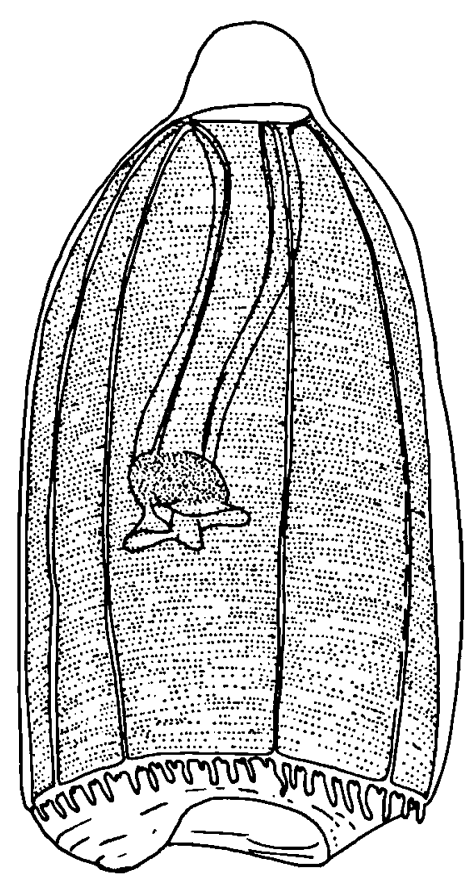

Fig. 40. Aglantha digitale from station 76 trawl 32 . 


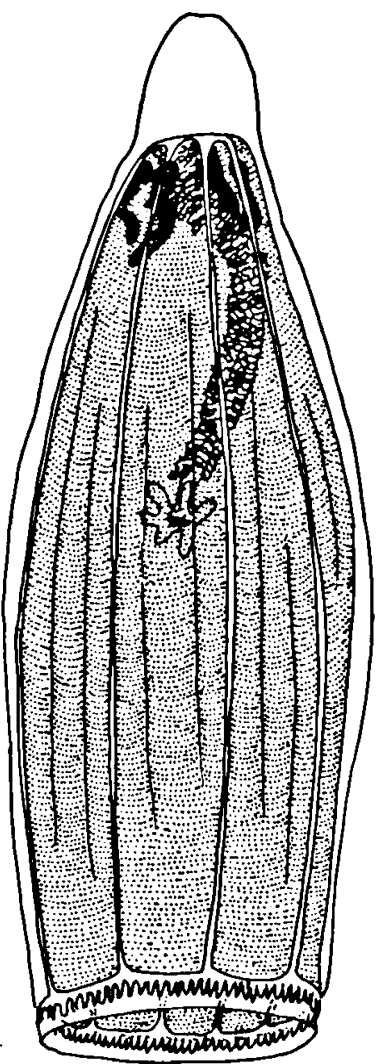

Fig. 41. Aglantha digitale from station 75 trawl 6.

between 0 and $1130 \mathrm{~m}$ with great abundance between 0 and $100 \mathrm{~m}$ and between 500 and $1000 \mathrm{~m}$. In spring it is found from $55^{\circ}$ to $39^{\circ} \mathrm{N}$, in summer from $55^{\circ}$ to $25^{\circ} \mathrm{N}$, and in autumn from $55^{\circ}$ to $48^{\circ} \mathrm{N}$. It is thus a northern species that penetrates the whole area investigated in summer. This southwards penetration is a penetration in deeper layers only. The species occurred south of $40^{\circ} \mathrm{N}$ only in the twilight samples so that nothing on vertical migration can be concluded, but north of $40^{\circ} \mathrm{N}$ no migration was found and south of $40^{\circ} \mathrm{N}$ it occurs only deeper than $500 \mathrm{~m}$. The distribution is probably from $60^{\circ}$ to $40^{\circ} \mathrm{N}$ (fig. 42) in shallow and deeper layers and from $40^{\circ}$ to $20^{\circ} \mathrm{N}$ only in deeper layers. Data on the southern oceans are too scarce to make conclusions, but the same patterns may exist there. The temperature and salinity ranges are 3.5$18.0^{\circ} \mathrm{C}$ and $34.72-35.74 \%$, respectively.

Family GERYONIIDAE

(49) Geryonia proboscidalis (Forskål, 1775) (8 spm) was found in spring and autumn at night between 40 and $395 \mathrm{~m}$ and at daytime between 200 and $1090 \mathrm{~m}$ depth at temperatures of $9.8-22.2^{\circ} \mathrm{C}$.

(50) Liriope tetraphylla (Chamisso \& Eysenhardt, 1821) (2 spm) was only found in spring in the upper $100 \mathrm{~m}$ at temperatures of $17.2^{\circ}$ $21.2^{\circ} \mathrm{C}$ at night.

\section{Order NARCOMEDUSAE}

Family AEGINIDAE

(51) Aegina citrea Eschscholtz, 1829 (figs. 43, 44) (67 spm) is a deep-sea species showing diurnal vertical migration as $42 \%$ of the population crosses the $300 \mathrm{~m}$ level daily. It seems to live shallower south of $38^{\circ} \mathrm{N}$. It is found in spring between $53^{\circ} 00^{\prime}$ and $24^{\circ} 44^{\prime} \mathrm{N}$, in summer between $54^{\circ} 24^{\prime}$ and $24^{\circ} 49^{\prime} \mathrm{N}$, in autumn between $50^{\circ} 57^{\prime}$ and $35^{\circ} 07^{\prime} \mathrm{N}$, and in winter between $40^{\circ} 55^{\prime}$ and $39^{\circ} 36^{\prime} \mathrm{N}$. The temperature and salinity ranges are $4.5-16.5^{\circ} \mathrm{C}$ and 35.09 $35.81 \%$, respectively. Always found below $100 \mathrm{~m}$ and at daytime mainly below $300 \mathrm{~m}$.

(52) Aeginura grimaldii Maas, 1904 (fig. 45) (2480 spm) was found at daytime always below $500 \mathrm{~m}$ and at night only 5 specimens were collected above this level. In 5 daytime samples below $1000 \mathrm{~m} 27$ specimens were found and in 4 night samples below $1000 \mathrm{~m} 77$ specimens were collected. It is thus a deep-living species without normal diurnal vertical migration. The upper limit of vertical distribution seems to slope down from $40^{\circ} \mathrm{N}$ towards the south when the single shallow sample at station 85 trawl 15 is neglected. The species occurred along the entire transect $55^{\circ} \mathrm{N}-24^{\circ} \mathrm{N}$ in all seasons. The temperature and salinity ranges are 3.5$19.2^{\circ} \mathrm{C}$ and $34.75-3648 \%$, respectively. 


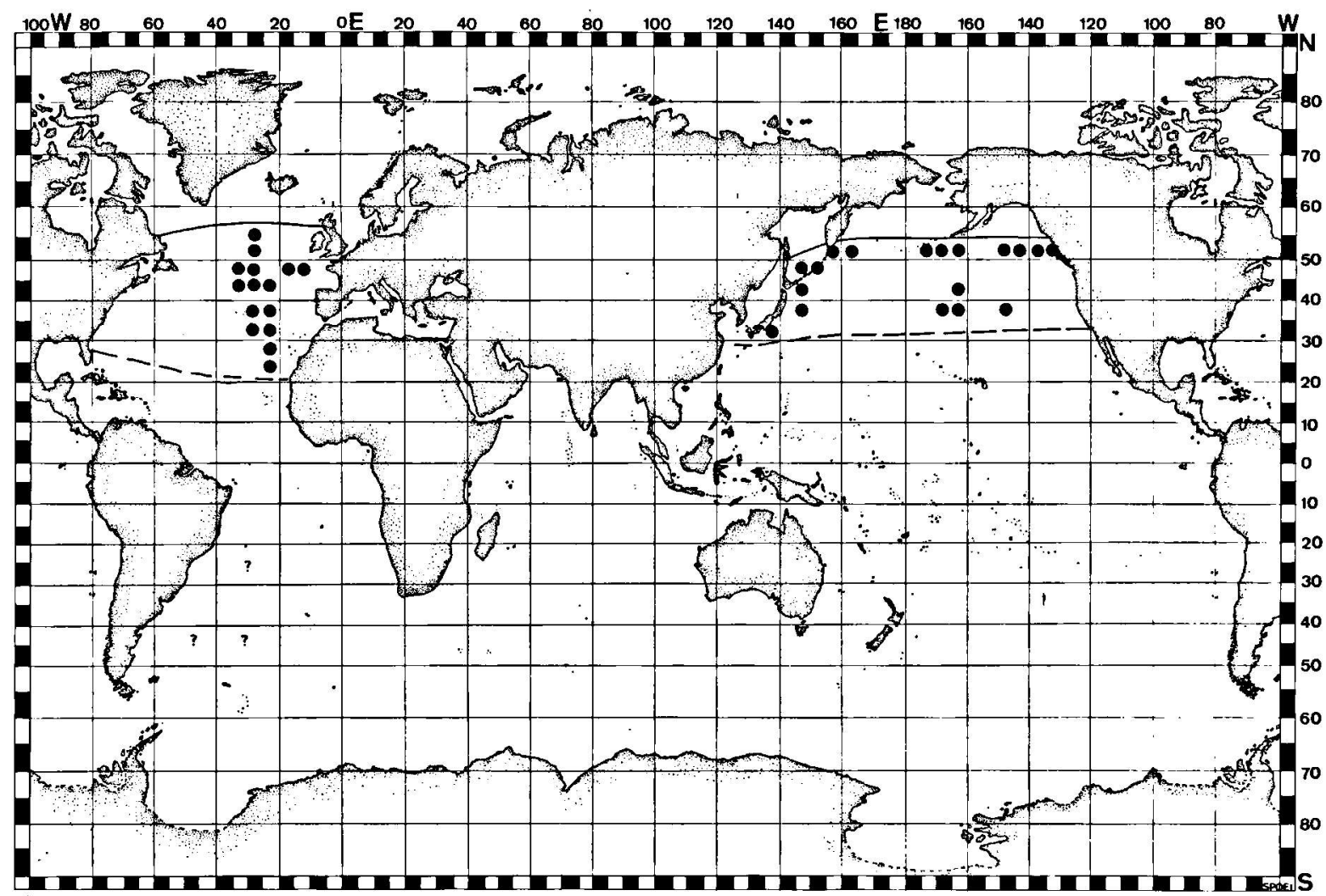

Fig. 42. Distribution of Aglantha digitale.

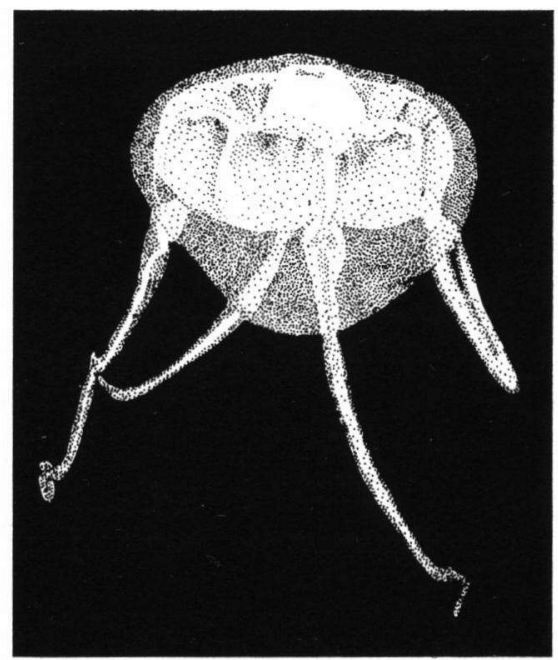

Fig. 43. Aegina citrea (after colour photograph) from station 39 trawl 14.

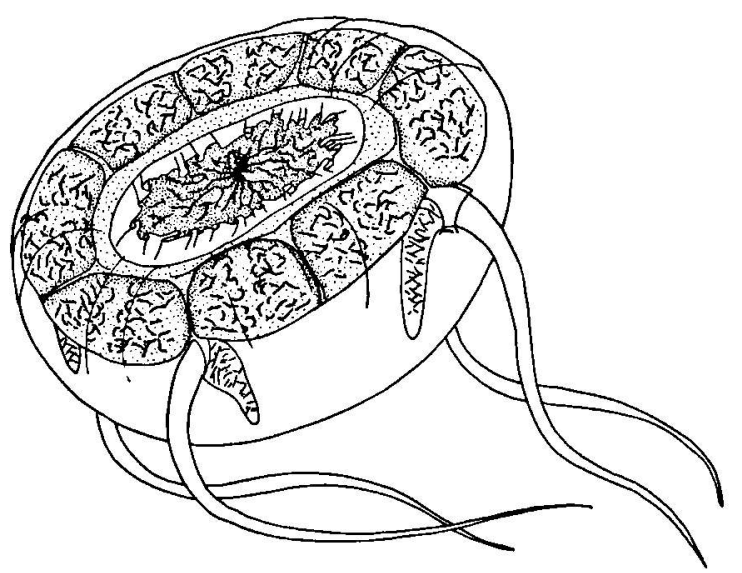

Fig. 44. Aegina citrea from station 84 trawl 37. 


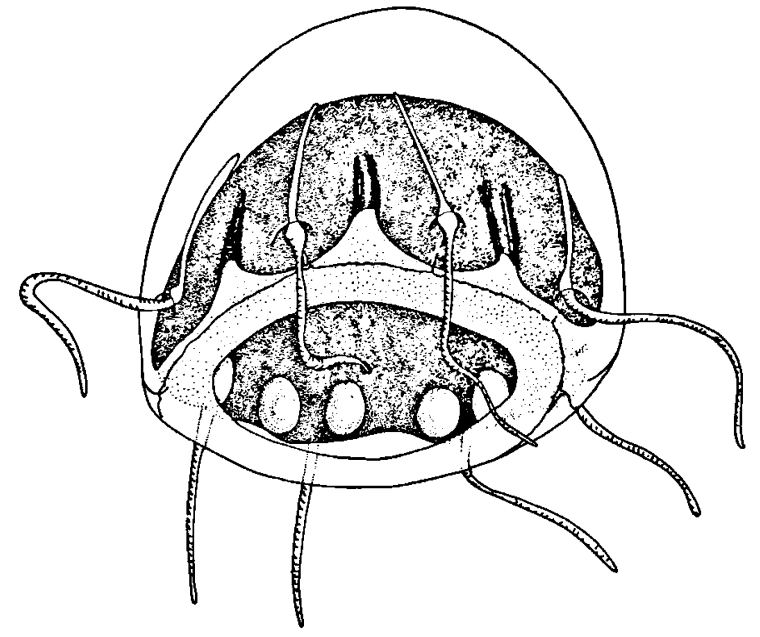

Fig. 45. Aeginura grimaldii from station 81 trawl 6.
This species is widely distributed in all oceans (fig. 46) between $60^{\circ} \mathrm{N}$ and $50^{\circ} \mathrm{S}$.

Family SOLMARIDAE

(53) Solmaris flavescens (Kölliker, 1853) (fig. 47) (17 spm) is probably a diurnal migrant as all night samples were from depths of 40 to $115 \mathrm{~m}$ and the daytime samples from depths of 195 to $1000 \mathrm{~m}$. It was collected in spring at $37^{\circ} 48^{\prime} \mathrm{N}$, in summer at $29^{\circ} 56^{\prime} \mathrm{N}$ and in winter between $40^{\circ} 57^{\prime}$ $30^{\circ} \mathrm{N}$. The temperature and salinity ranges are $9.9-19.2{ }^{\circ} \mathrm{C}$ and $35.69-36.00 \%$, respectively.

(54) Solmaris solmaris (Gegenbaur, 1856) (13 spm) was collected only in night samples at depths between 0 and $528 \mathrm{~m}$ during summer and winter, only south of $42^{\circ} \mathrm{N}$. The temperature and salinity ranges are 13.0$20.3^{\circ} \mathrm{C}$ and $35.80-36.48 \%$, respectively.

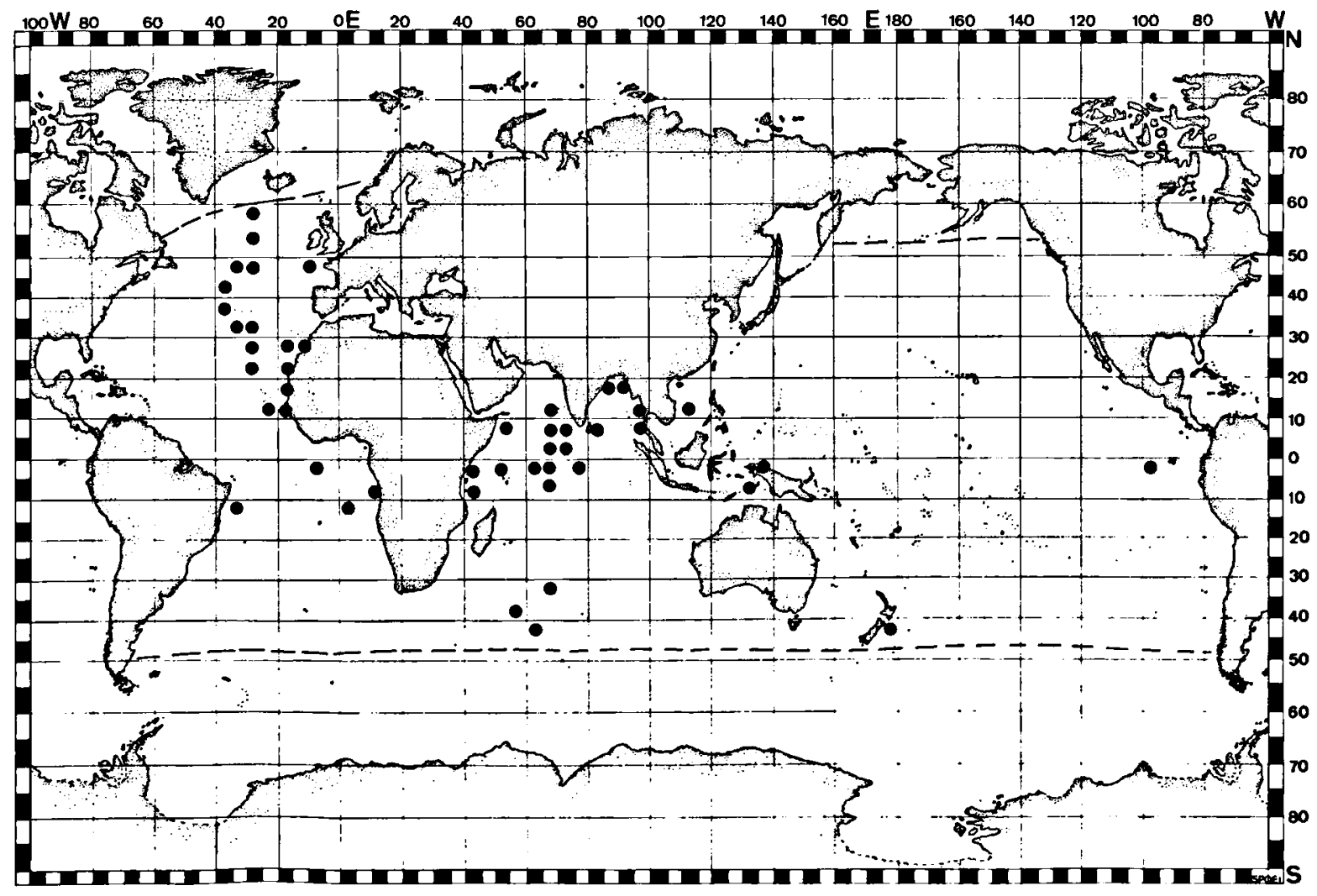

Fig. 46. Distribution of Aeginura grimaldii. 


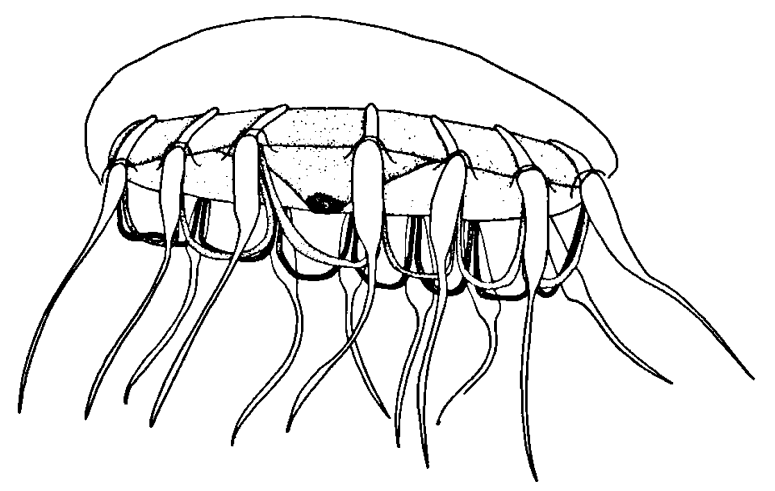

Fig. 47. Solmaris flavescens from station 987 trawl 25.

(55) Solmaris corona (Keferstein \& Ehlers, 1861) (1 spm) was collected near the Great Meteor Bank $\left(30^{\circ} \mathrm{N}\right)$ in a deep haul between 752 and $1005 \mathrm{~m}$ in summer. The temperature was $9.7^{\circ} \mathrm{C}$ and the salinity was $35.63 \%$.

(56) Pegantha laevis Bigelow, 1909 (80 spm) is clearly a vertical migrant as $65 \%$ of the population passes daily the $200-300 \mathrm{~m}$ depth stratum. It occurred at night between 0 and $500 \mathrm{~m}$ but at daytime it was only found in the 100-500 m layer as an upper mesopelagic species. Most records are from spring between $49^{\circ} 01^{\prime}$ and $32^{\circ} 07^{\prime} \mathrm{N}$, while a few records in autumn were made between $50^{\circ} 49^{\prime}$ and $35^{\circ} 06^{\prime} \mathrm{N}$. The temperature and salinity ranges are $10.9-17.5^{\circ} \mathrm{C}$ and $35.35-36.02 \%$, respectively.

(57) Pegantha martagon Haeckel, 1879 (68 spm) was always more abundant in the night samples as compared to the day samples. Moreover, $8-16 \%$ of the population crosses daily the $200-500 \mathrm{~m}$ depth level so that vertical migration is tracable. The species occurred in spring and autumn only and was found between $41^{\circ} 31^{\prime}$ and $24^{\circ} 48^{\prime} \mathrm{N}$ and between $37^{\circ} 05^{\prime}$ and $25^{\circ} 10^{\prime} \mathrm{N}$, respectively. The temperature and salinity ranges are $9.9-19.3^{\circ} \mathrm{C}$ and 35.53-27.23\%.

(58) Pegantha clara Bigelow, 1909 (23 spm) shows vertical migration as all specimens collected at daytime were from below 200 $\mathrm{m}$ and those collected at night were from depths shallower than $200 \mathrm{~m}$. The species was found in spring, summer, autumn and winter in low numbers at $38^{\circ} 00^{\prime} \mathrm{N}$ $29^{\circ} 48^{\prime} \mathrm{N}$, at $44^{\circ} 59^{\prime} \mathrm{N}-41^{\circ} 01^{\prime} \mathrm{N}$, at $47^{\circ} 49^{\prime} \mathrm{N}-28^{\circ} 03^{\prime} \mathrm{N}$ and at $40^{\circ} 55^{\prime} \mathrm{N}-$ $30^{\circ} 02^{\prime} \mathrm{N}$, respectively. The temperature and salinity ranges are $12.8-19.2^{\circ} \mathrm{C}$ and $35.35-36.29 \%$, respectively.

(59) Pegantha rubiginosa (Kölliker, 1853) (3 spm) was found in summer and winter at $41^{\circ} 37^{\prime}$ and $29^{\circ} 59^{\prime} \mathrm{N}$, respectively and at depths between 103 and $445 \mathrm{~m}$. The temperature is $14.9^{\circ} \mathrm{C}$ and the salinity is $36.13 \%$.

(60) Pegantha triloba Haeckel, 1879 (2 spm) was found only once in winter between 30 and $110 \mathrm{~m}$ at $30^{\circ} 02^{\prime} \mathrm{N}$ with a local temperature of $19.4^{\circ} \mathrm{C}$. At this locality also Bougainvillia platygaster was found.

Pegantha spec. (141 spm) are probably damaged specimens of $P$. laevis or $P$. martagon. These specimens were most abundant in spring between $48^{\circ} 59^{\prime} \mathrm{N}$ and $28^{\circ} 20^{\prime} \mathrm{N}$ but they were also found in autumn between $45^{\circ} 03^{\prime}$ and $28^{\circ} 07^{\prime} \mathrm{N}$ and in winter at $40^{\circ} 56^{\prime} \mathrm{N}$. A strong migration seems present as $40 \%$ of the population crosses the $500 \mathrm{~m}$ level and $46 \%$ crosses the $100 \mathrm{~m}$ level daily.

Family CUNINIDAE

(61) Cunina duplicata Maas, 1893 (2 spm) was found in summer at $41^{\circ} 39^{\prime} \mathrm{N}$ and $24^{\circ} 52^{\prime} \mathrm{N}$; it was collected at night between 51 and $105 \mathrm{~m}$ and at twilight between 515 and $1000 \mathrm{~m}$. The temperatures at these localities were $9.4^{\circ}-15.4^{\circ} \mathrm{C}$.

(62) Cunina frugifera Kramp, 1948 (2 spm) was found only in summer at $41^{\circ} 34^{\prime} \mathrm{N}$ at 198 $340 \mathrm{~m}$. The local temperature and salinity are $14.2^{\circ} \mathrm{C}$ and $36.00 \%$.

(63) Cunina peregrina Bigelow, 1909 (4 spm) was collected only in one haul of 40 to $115 \mathrm{~m}$ depth during winter at $30^{\circ} 02^{\prime} \mathrm{N}$, temperature $19.2^{\circ} \mathrm{C}$.

(64) Solmissus marshalli Agassiz \& Mayer, 1902 (fig. 48) (5 spm) is a shallow-living species, 


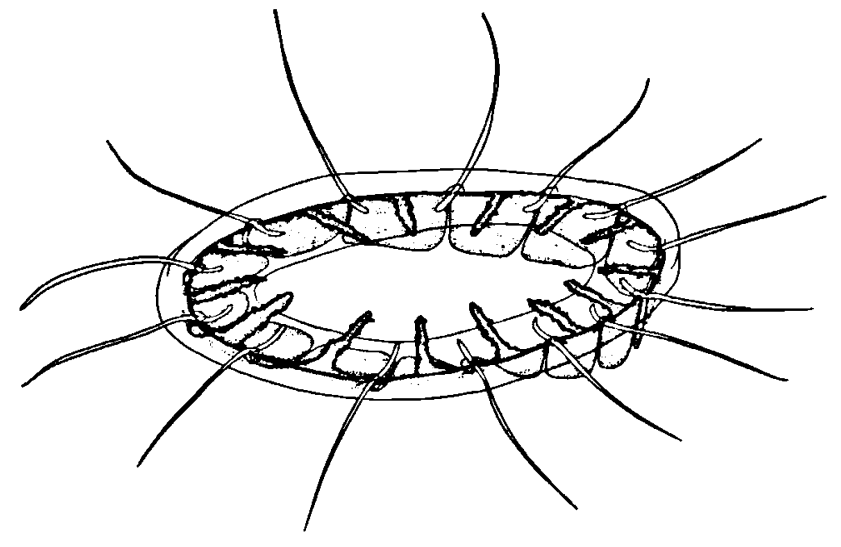

Fig. 48. Solmissus marshalli from station 87 trawl 1. though considered by Kramp (1959) as deep-living, found between 0 and $200 \mathrm{~m}$, in spring at $28^{\circ} 20^{\prime} \mathrm{N}$, in summer at $29^{\circ} 59^{\prime} \mathrm{N}$, and in winter at $29^{\circ} 58^{\prime} \mathrm{N}$. The temperature and salinity at depth are $19.2^{\circ} \mathrm{C}$ and $36.75 \%$.

(65) Solmissus incisa (Fewkes, 1886) (65 spm) is a deep-living species (fig. 49). At night the whole population was found below $500 \mathrm{~m}$ but at daytime specimens are found as well between 30 and $100 \mathrm{~m}(1 \mathrm{spm}), 200$ and $300 \mathrm{~m}$ (2 spm), 300 and $400 \mathrm{~m} \mathrm{(4} \mathrm{spm)} \mathrm{and}$ between 400 and $500 \mathrm{~m}(4 \mathrm{spm})$, but most animals are from deeper strata. The species is found between $53^{\circ}$ and $33^{\circ} \mathrm{N}$ in spring, between $54^{\circ}$ and $24^{\circ} \mathrm{N}$ in summer, between $55^{\circ}$ and $27^{\circ} \mathrm{N}$ in autumn, and at $30^{\circ} \mathrm{N}$ in winter. The temperature range is $3.5^{\circ}-19.4^{\circ} \mathrm{C}$ and the salinity range is $34.75-35.87 \%$.

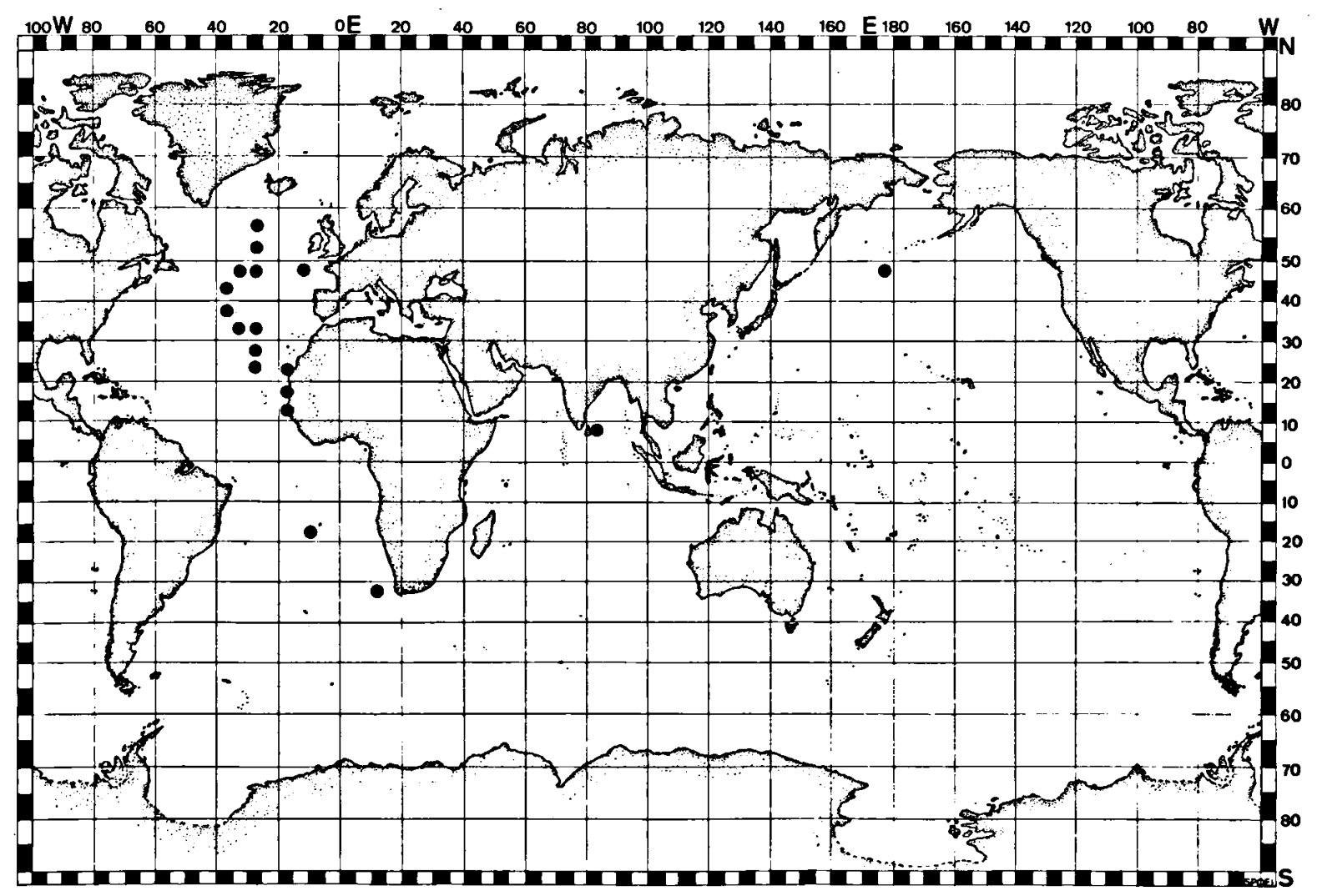

Fig. 49. Distribution of Solmissus incisa. 


\section{TAXONOMIC NOTES}

\section{Sibogita geometrica Maas, 1905}

The variability in this species is very large; for a discussion on the validity of the subsp. occidentalis Kramp, 1959 one is referred to Winkler (1982) and Van der Spoel \& Bleeker (1988).

Crossota spec. (fig. 30)

The specimen from station 81 trawl 6 at $40^{\circ} 56^{\prime} \mathrm{N}$ between 500 and $1000 \mathrm{~m}$ was not attributed to one of the known species though its preservation was good. It had all the characters of the family Rhopalonematidae and of the genus Crossota. There are 8 radial canals in the specimen, the gonads are close to the stomach at the apical point of the canals and there are about 160 marginal tentacles. So the principle characters of $C$. rufobrunnea are present. The extreme length of the manubrium, reaching halfway the umbrella cavity and the very large oral lips do not occur in C. rufobrunnea, however. As different contractions during fixation and preservation may strongly affect manubrium length, no new species for the present specimen is proposed, the more so as no other discrimating characters have been found.

\section{Oceania tydemani n. sp. (fig. 7)}

Description: Umbrella $8 \mathrm{~mm}$ in diameter and 5 $\mathrm{mm}$ high, manubrium $3 \mathrm{~mm}$ in diameter. The medusa is flatly topped. The jelly is thin. Gonads adradial on stomach wall; as they are not fully developed they are seen as small warts only. There is a short peduncle without vacuoles. The manubrium is broad and half as long as the umbrella cavity, quadrangular in cross section. The four lips are only partly lined with nematocysts as the interradial area is lacking nematocysts. There are four simple narrow radial canals. Adaxial ocelli present. No statocysts. The velum is broad. There are 180 solitary marginal tentacles placed in a double, zigzag row.

Holotype: ZMA coll. no. Coel. 5598; 101A project station 48 trawl 13.
Type locality: $34^{\circ} 11.4^{\prime} \mathrm{N} 31^{\circ} 11.3^{\prime} \mathrm{W}, 60$ $100 \mathrm{~m}$, temperature $18.7^{\circ} \mathrm{C}, 23-\mathrm{IX}-1981$, daytime sample.

Etymology: The name is given after the oceanographic research vessel H.M.S. "Tydeman", the platform for the 101A project cruises.

The most closely related species is $O$. armata, but it differs as the lining of the lips with nematocysts is continuous, and the number of tentacles is only up to 100 . The discontinuous lining with nematocysts is not in agreement with the diagnosis of the family (Kramp, 1959), but the other characters of the specimen are evidently showing that it belongs to the genus Oceania and family Clavidae.

\section{Annatiara lempersi n. sp. (fig. 13)}

Description: Umbrella bell-shaped, $8 \mathrm{~mm}$ high and $16 \mathrm{~mm}$ in diameter, the jelly is thick and there is no apical projection, exumbrella with nematocyst tracks at each tentacle. Velum small. Stomach short, four-sided but not attached to subumbrella as described for $A$. affinis, the radial canals do reach only halfway the umbrella and in between the tops of the canals a square is formed by the stomach walls so that the stomach is expanded interradially. The musculature in the umbrella is intact and not distorted so that the configuration of the stomach can not be due to damage. Mouth with strongly folded lips. The four radial canals run from the perradial corners of the interradial square of the stomach to the ring canal. The gonads are probably not yet fully developed, they line the stomach as strongly folded bands. There are 24 hollow smooth marginal tentacles, which are typically curled in the preserved specimen; no abaxial spurs, only a small basal swelling present. One small rudimentary tentacle between each two normally developed tentacles. Abaxial ocelli present on all tentacles.

Holotype: ZMA coll. no. Co. 5932; 101A project station 84 trawl 36 .

Type locality: $35^{\circ} 1.0^{\prime} \mathrm{N} 31^{\circ} 30.9^{\prime} \mathrm{W}, 300$ $400 \mathrm{~m}$, temperature $12.65^{\circ} \mathrm{C}, 6$-VI-1983, dusk sample. 
Etymology: The name is given in honour of the commander of H.M.S. "Tydeman", KLTZ Ir. A. P. H. M. Lempers.

The most closely related species is Annatiara affinis from which it differs in having only 24 tentacles (28-44 in A. affinis, 32 in the material of station 87), a stomach attached along an interradial square (along a perradial cross in $A$. affinis).

\section{FAUNAL BORDERS}

Winkler (1982) found a faunal boundary zone for epi- and mesopelagic Hydromedusae at $38^{\circ}$ $40^{\circ} \mathrm{N}$. The latitudinal occurrence of all species is given in fig. 50 .

Especially for the spring cruise (1980) (cf. Winkler, 1982) but also for the summer cruise (1983) a faunal border was found near $40^{\circ}$. $42^{\circ} \mathrm{N}$. The autumn cruise did not show clear transitions to be based on first and last occurrence of taxa, and the winter cruise made too few stations to use this method. The summer cruise showed high numbers of first and last occurrence at $45^{\circ}, 42^{\circ}, 35^{\circ}$, and $30^{\circ} \mathrm{N}$.

Mathematically the investigation of first and last occurrence can be refined. However, this and many other methods to detect faunal borders or significant differences between samples are mainly based on statistical methods. For biology, however, it seems appropriate to develop a method based on biological principles.

One can start with the theoretical assumption that species have no value for a sample when they do not contribute to the diversity of the sample and when they do not determine the sample's quality by their dominance. The importance of the species for a sample is thus greater when its distance to the point where its dominance value and its diversity value are zero is greater. This can be expressed in the formula:

$$
B=\sqrt{ }\left(D^{2}+C^{2}\right)
$$

$B=$ the computed value of the species for the sample in which it is present, or the specific loading; $C=$ the value a species adds to the quality of the sample by its dominance; $D=$ the value a species adds to the quality of the sample by its contribution to the diversity.

The dominance value $(C)$ of a species in a specific sample is dependent on the number of specimens relative to the abundance of that species in other samples and on the total number of species in the sample relative to that number in other samples. The following formula is proposed to express the dominance value:

$C=100 \times(F \cdot N-\Sigma N) /\left(F \cdot N_{\max }-\Sigma \mathrm{N}\right) \times F / F_{\max }$ $F=$ number of species in the sample; $N=$ number of specimens of the species in the sample; $N_{\max }=$ number of specimens of the most abundant species in the sample; $F_{\max }=$ number of species in the most diverse sample.

The diversity value $(D)$ of a species in a specific sample is likewise dependent on the number of specimens in the sample, but relative to the number of samples in which the species is found and relative to the number of species found in other samples. The following formula is proposed to express the diversity value:

$$
D=\sqrt{ }\left(1+A_{\max }-A\right)^{2} \times(1+M-A) \times N
$$

$M=$ total number of samples in the study; $A=$ number of samples in which the species is found; $A_{\max }=$ maximum value for $A$ for the series of samples studied.

The total abundance and diversity of a sample, the sample loading, is the sum of all the specific loadings of one sample. The greater the difference of $\Sigma B$ of two samples, the greater are the differences in abundance, dominance and diversity of the samples.

The $\Sigma B$ for a hypothetical series of samples and species is given in table I.

In the equation $\Sigma B=\Sigma \sqrt{ }\left(D^{2}+C^{2}\right)$ diversity value $(D)$ has a much greater influence on the value of $\Sigma B$ than the dominance value has, so in the comparisons also $\Sigma \sqrt{ } C^{2}$ is used separately.

The results of this method for the North Atlantic Medusae are shown in figs. 51-54. In spring (1980) (fig. 51) $\Sigma \mathrm{B}$ is on the average much larger north of $40^{\circ} \mathrm{N}$ than to the south of that latitude. Between $38^{\circ} \mathrm{N}$ and $42^{\circ} \mathrm{N}$ the $\Sigma \sqrt{ } C^{2}$ is much larger than at other localities. So 

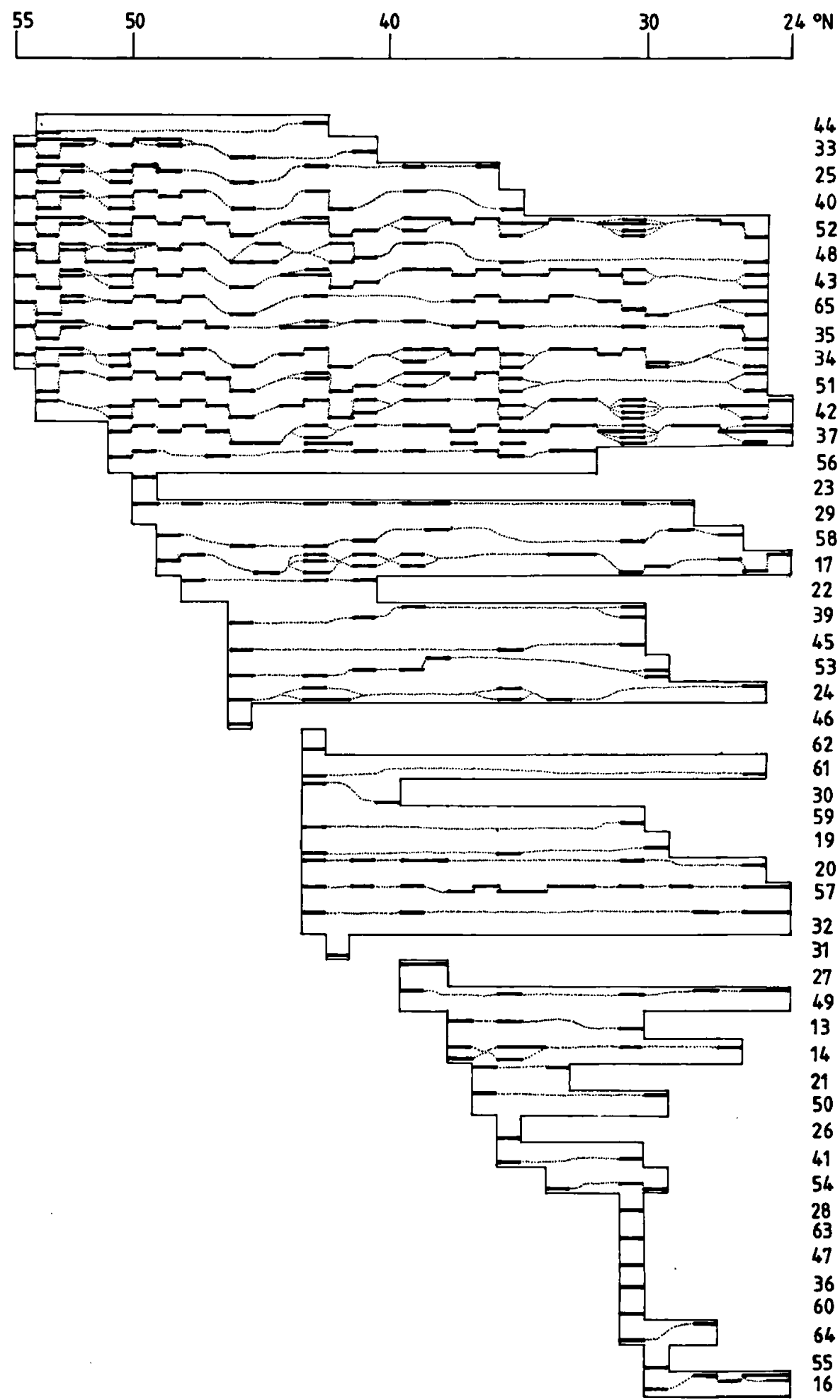

Amphogona apsteini Botrynema brucei Chromatonema rubrum Crossota rufobrunnea Aeginura grimaldii Aglantha digitale Pantachogon haeckeli Solmissus incisa Haliscera bigetowi Halicreas minimm Aegina citrea Colobonema sericeum Rhopalonema velation Pegantha Laevis Bythotiara murrayi Tima flavilabris Pegantha clara Annatiora affinis Calycopsis gara Crossota alba Amphogona apicata Solmaris flavescens. Sibogita geometrica Tetrorchis erythrogaster. Cunina frugifera Cunina duplicata Zygocarna vagans Pegantha rubiginosa Pandea rubra Pandea conica Pegantha martagon Halitrephes maasi Aequorea tenuis Cosmetira pizoselza Geryonia probosaidalis Cytaeis tetrastyla Oceania armata Neoturris pileata Liriope tetraphylla Cuvieria huxleyi Sminthea eurygaster Solmaris solmaris Phialopsis diegensis Cunina peregrina Agloura hemistoma Rhopalonema funeraxion Pegantha triloba Solmissus marshalli Solmaris corona Bougainvillia platygaster

Fig. 50. The latitudinal distribution of the species of Hydromedusae. Along the horizontal axis degrees north, along the vertical axis the species. For each species a bar is used in which a dotted line connects the thick lines, indicating presence, situated: for spring in the top, for autumn above the centre, for winter under the centre and for summer at the bottom of each bar. 
TABLE I

$\Sigma B$ for a hypothetical series of stations (a-g) and species (I-VI)

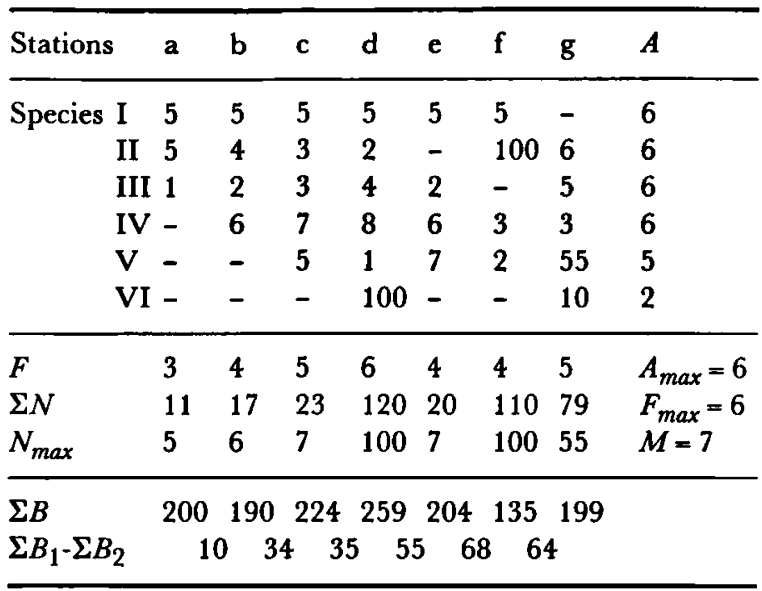

a less diverse subpolar fauna with some abundant species lives north of $40^{\circ} \mathrm{N}$ and to the south lower abundances are found in a warmwater fauna. The mixing of the cold- and warm-water faunas gives the high diversity between $38^{\circ} \mathrm{N}$ and $42^{\circ} \mathrm{N}$.
In summer (1983) (fig. 54) at $45^{\circ} \mathrm{N}$ but more pronounced at $50^{\circ} \mathrm{N}$ the abundance increases compared to the lower latitudes; the diversity maxima are found near $25^{\circ} \mathrm{N}, 35^{\circ} \mathrm{N}$ and $41^{\circ}$. $42^{\circ} \mathrm{N}$. The maximum at $35^{\circ} \mathrm{N}$ may indicate the transition of Sargasso Sea and temperate waters (cf. Van der Spoel, 1985). The transition between temperate and North Atlantic Drift waters is found near $45^{\circ} \mathrm{N}$, but the maximum at $41^{\circ}-42^{\circ} \mathrm{N}$ may still be correlated with this transition. The high abundance in subpolar waters is reflected by the high $\Sigma B$ value north of $50^{\circ} \mathrm{N}$.

In autumn (1981) (fig. 52) a picture comparable to the spring situation is found with high abundances north of $48^{\circ} \mathrm{N}$ and a diversity maximum near $48^{\circ} \mathrm{N}$ but also near $34^{\circ}-37^{\circ} \mathrm{N}$. North of $48^{\circ} \mathrm{N}$ the subpolar fauna with some abundant species is found, it mixes near $48^{\circ} \mathrm{N}$ with the temperate, North Atlantic Drift fauna. The transition of subtropical and temperate faunas is more evident in autumn than in spring as this transition near $34^{\circ}-37^{\circ} \mathrm{N}$ is marked by high diversity only in autumn.

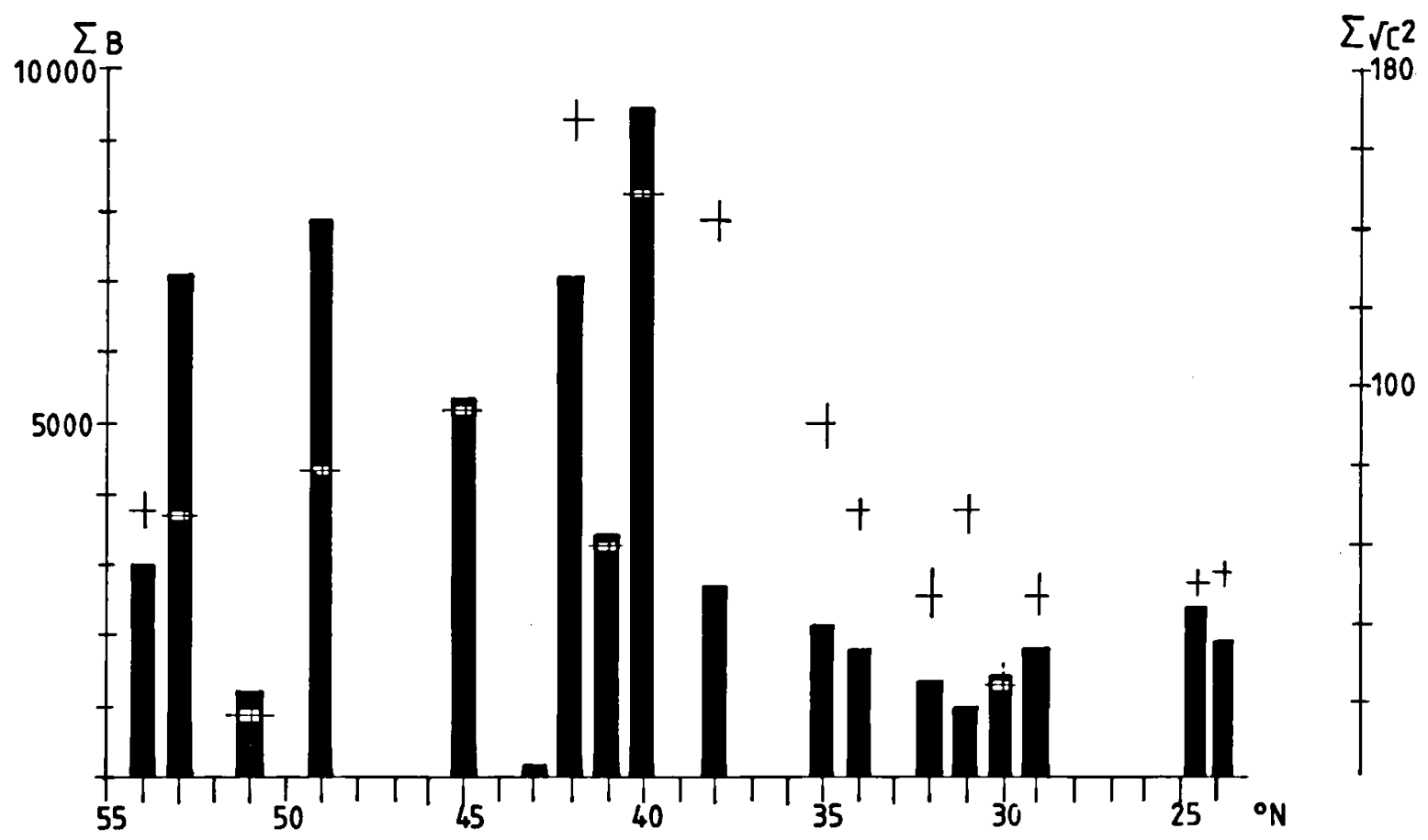

Fig. 51. Diversity abundance analyses for the samples of the 1980 cruise, vertical axes for $\Sigma B$ and $\Sigma \sqrt{ } C^{2}$, horizontal axis latitude north, columns indicate the $\Sigma b$ value, the crosses indicate the $\Sigma \sqrt{ } C^{2}$ values. 
BIJDRAGEN TOT DE DIERKUNDE, 58 (2) - 1988

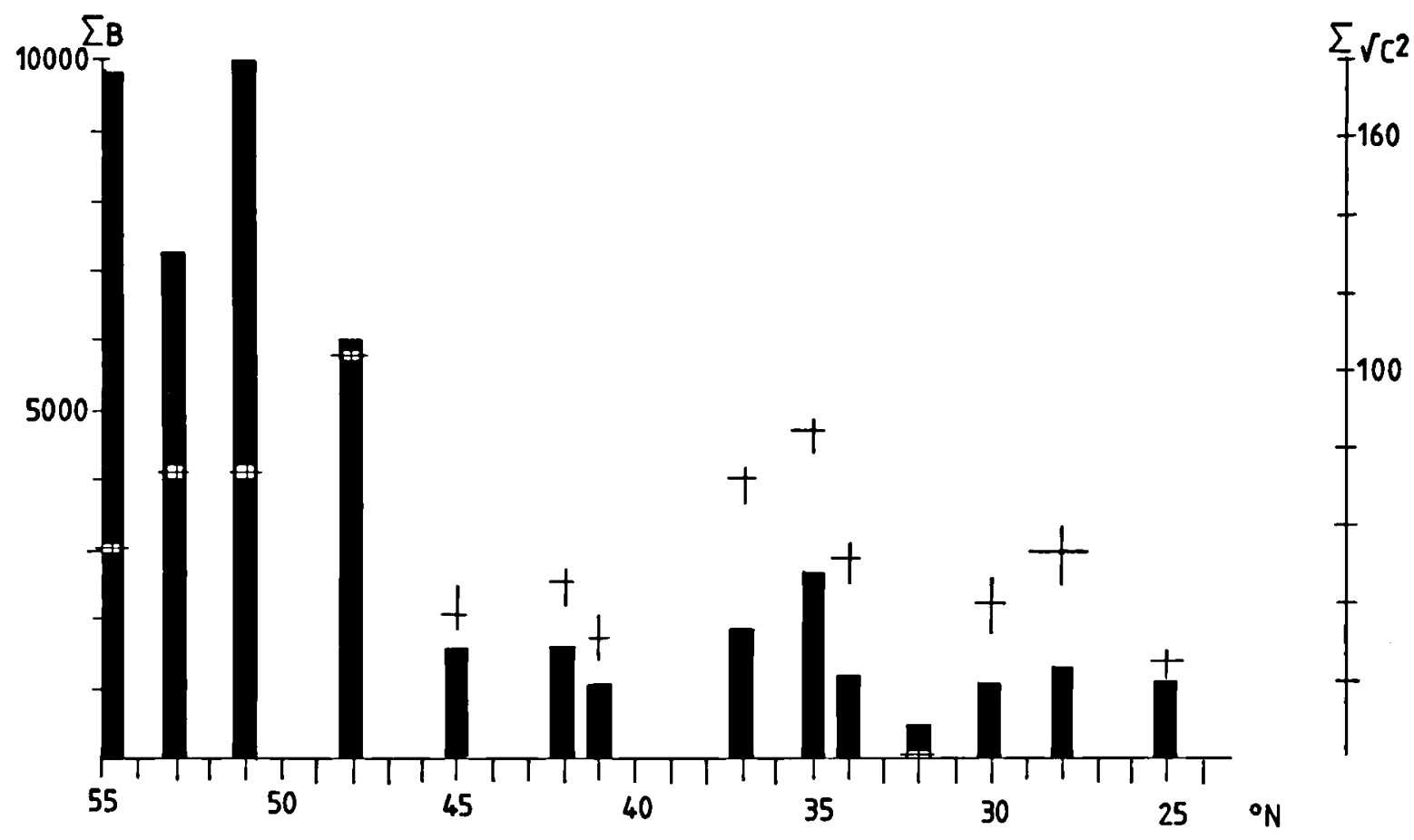

Fig. 52. Diversity abundance analyses for the samples of the 1981 cruise, for explanation see fig. 51.

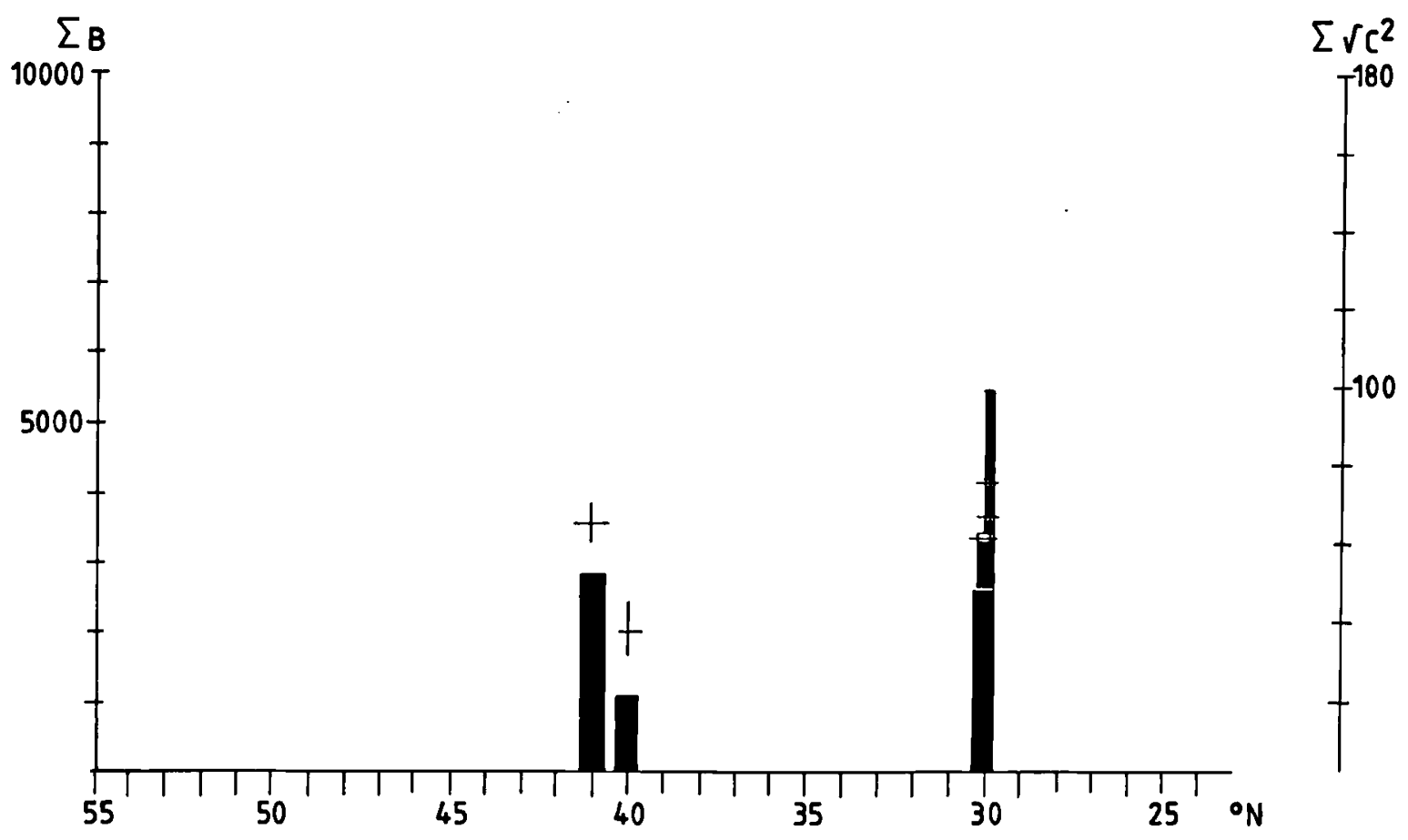

Fig. 53. Diversity abundance analyses for the samples of the 1982 cruise, for explanation see fig. 51. 


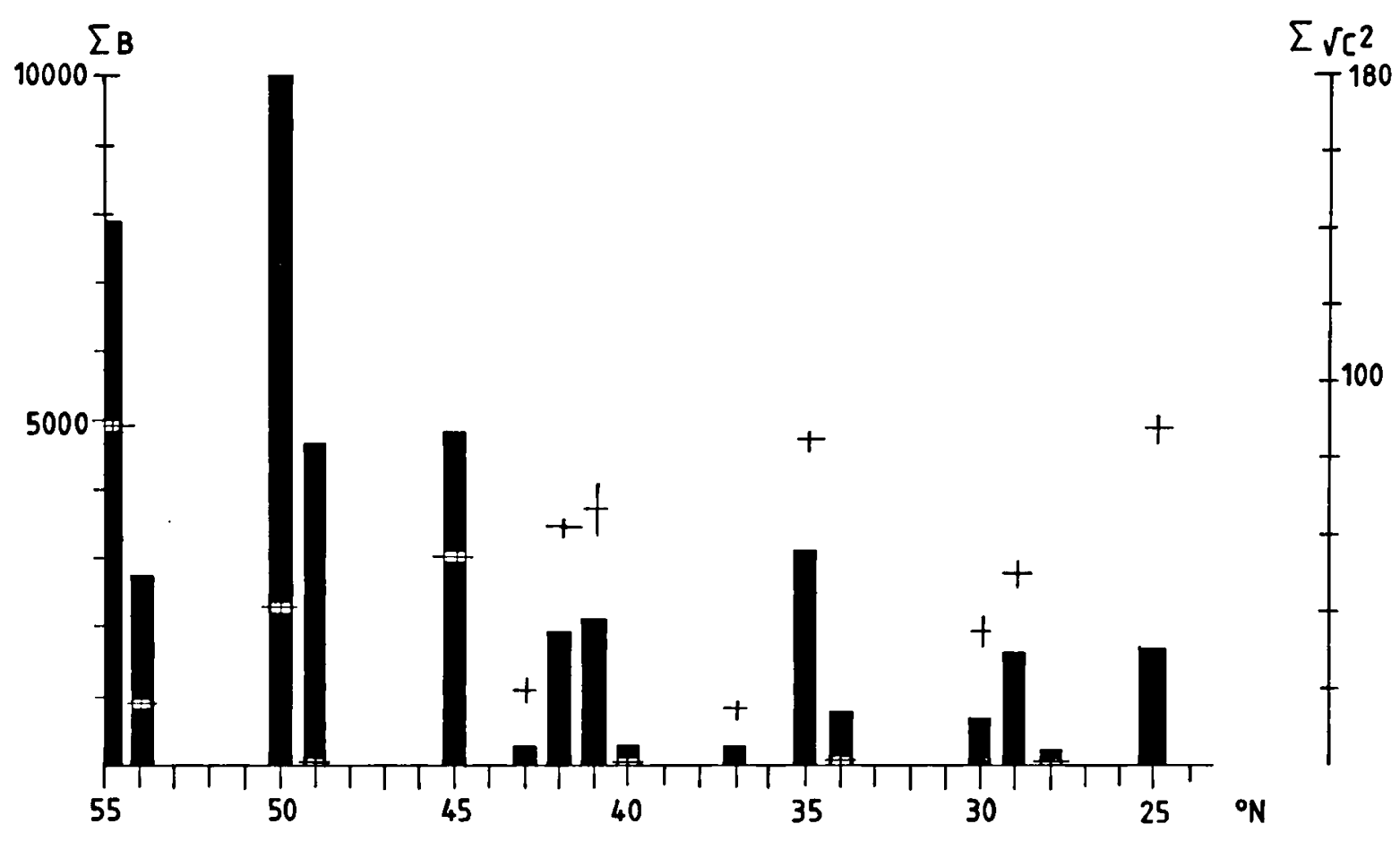

Fig. 54. Diversity abundance analyses for the samples of the 1983 cruise, for explanation see fig. 51.

The abundances in spring, autumn, and summer are comparable, though in spring the area south of $40^{\circ} \mathrm{N}$ shows somewhat higher values. In winter (fig. 53) the $\Sigma B$ values near $41^{\circ} \mathrm{N}$ are lower than in summer and autumn, near $30^{\circ} \mathrm{N}$ the $\Sigma B$ values are evidently higher than in the other seasons.

As a conclusion it can be stated that the subpolar fauna penetrates in spring southwards to about $40^{\circ} \mathrm{N}$ and retracts to $50^{\circ} \mathrm{N}$ in summer, in autumn it again spreads southwards to $48^{\circ} \mathrm{N}$ and in winter it shows its lowest abundance. In summer the subtropical fauna is most evidently present probably by northward penetration to about $35^{\circ} \mathrm{N}$. This pattern deduced from Hydromedusae of the upper $1000 \mathrm{~m}$ of the water column is also shown by Radiolaria from the upper $5 \mathrm{~m}$ of the water column (Van der Spoel, 1987b).

Chromatonema rubrum is mentioned as a species sensitive to seasonal changes. It is not a temperate species (fig. 22) though it behaves like such a type of element in the North Atlan- tic. Its seasonal migration consists of withdrawal to colder waters either to the north or to the depth.

\section{BATHYMETRIC DISTRIBUTION}

Most bathypelagic and eurybathypelagic species occur in all seasons along the entire transect of the cruise. Exceptions are Paraphyllina ransoni that is only found in summer, Halitrephes maasi that is only found in spring and the bathypelagic species that do not occur south of $42^{\circ} \mathrm{N}$ : Haliscera bigelowi, Chromatonema rubrum, and more explicitly Botrynema brucei and Aglantha digitale, both species of the higher latitudes showing strong subtropical submergence.

Aeginura grimaldii is also a species with subtropical submergence but as it is frequently recorded from lower latitudes, which is not the case in Aglantha digitale, it is probably sinking to a less deep submergence in the tropical region. 
That $P$. periphylla shows shallow occurrence at lower latitudes, viz. at stations 22 and 49 is probably due to upwelling near shallow banks, as already mentioned by Van Utrecht (1982).

Table II gives a survey of the seasonal occurrence of the species in the area north of $42^{\circ} \mathrm{N}$ with winter mixing and south of $42^{\circ} \mathrm{N}$ with permanent stratification. The bathymetric occurrence is given at the right in the table. Some remarks should be made.

Annc'iara affinis is according to Kramp (1959) a deep and intermediate species. In the present material it also showed up in shallow layers and diurnal migration is found. Probably it can be better considered a eurybathic species. For Haliscera bigelowi and Rhopalonema funerarium also an eurybathic occurrence is found. The shallow and deep subtropical submergence of Aglantha digitale was already mentioned. Botrynema murrayi, Sminthea eurygaster, Pandea rubra and Rhopalonema funerarium are not found in very deep samples so that their bathypelagic nature is dubious. Crossota alba is like others also considered bathypelagic by Kramp (1959) but a record in the upper layers makes this doubtful.

From table II it is also clear that most deepliving taxa occur in all seasons along the whole cruise transect.

Though the mobility of medusae seems small, still for a number of taxa diurnal vertical migration is found. The Hydromedusae that show diurnal migration are: Bougainvillia platygaster, Annatiara affinis, Sibogita geometrica, Rhopalonema velatum, Pegantha martagon, $P$. laevis and $P$. clara. Dubious indications for diurnal migration are recorded for: Cytaeis tetrastyla, Pandea conica, Chromatonema rubrum, Pantachogon haeckeli and Solmissus incisa.

\section{CONCLUSIONS}

The medusa fauna of the upper $1000 \mathrm{~m}$ of the North Atlantic Ocean between $25^{\circ}$ and $55^{\circ} \mathrm{N}$ along approximately $30^{\circ} \mathrm{W}$ consists of 6 fanual elements:

(I) widely distributed bathy- and mesopelagic species like Halicreas minimum;
(II) widely spread eurybathypelagic species, like Rhopalonema velatum;

(III) species occurring in shallow layers at high latitudes but showing subtropical submergence like Aglantha digitale and Periphylla periphylla.

These three types are recorded for the entire N.-S. range of the area investigated.

(IV) Species occurring in the Atlantic Ocean only in the area around the Azores, like Zygocanna vagans. In the Indo-Pacific Oceans these species may have a wider distribution;

(V) species of the warmer waters occurring only in the southern stations of the area investigated, like Bougainvillia platygaster and Oceania armata;

(VI) the temperate species like Solmaris flavescens that are very difficult to trace as such in the present collections.

Vertical diurnal migration is found in representatives of most groups; for 7 species diurnal migration could be demonstrated and for 5 species it is expected to occur.

Exclusively epipelagic species were not found, most shallow-living - taxa are also recorded from depths below $200 \mathrm{~m}$, and a large number of species and a high percentage of specimens collected belong to meso- and bathypelagic species. This may explain why some of the faunal borders found for the Medusae (spring $40^{\circ}-42^{\circ} \mathrm{N}$; summer $50^{\circ}, 45^{\circ}$, $42^{\circ}, 35^{\circ}, 30^{\circ} \mathrm{N}$ and autumn $48^{\circ}$ and $34^{\circ}$ $37^{\circ} \mathrm{N}$ ) are also reflected in the distribution of Myctophidae and Mollusca (Van der Spoel, unpublished data). That there are also parallels with borders found for Radiolaria is more surprising but still understandable as these patterns are the result of the same hydrography and climate.

Two new species are described.

\section{ACKNOWLEDGEMENTS}

The authors are indebted to Drs. J. Th. Winkler for the permission to use his original notes and identifications of the 1980 and part of the 1981 material. Commanders and crews of H.M.S. "Tydeman" are thanked for the enthousiastic help during collecting of the material. 
TABLE II

Latitudinal and seasonal differences in distribution, with the division into four ecological groups.

\begin{tabular}{|c|c|c|c|c|c|c|c|c|c|c|c|c|}
\hline \multirow[t]{2}{*}{ Species } & \multicolumn{3}{|c|}{$>42^{\circ} \mathrm{N}$} & \multicolumn{4}{|c|}{$<42^{\circ} \mathrm{N}$} & \multicolumn{4}{|c|}{ Ecology } & \multirow[b]{2}{*}{$\left.{ }^{*}\right)$} \\
\hline & $\mathrm{Sp}$ & Su & $\mathrm{Au}$ & $\mathrm{Sp}$ & $\mathrm{Su}$ & $\mathrm{Au}$ & Wi & $\mathrm{Ba}$ & $\mathrm{Di}$ & $\mathbf{E u}$ & $\mathrm{Ep}_{\mathrm{p}}$ & \\
\hline Periphylla periphylla & $\mathbf{x}$ & $\mathbf{x}$ & $\mathbf{x}$ & $\mathbf{x}$ & $\mathbf{x}$ & $\mathbf{x}$ & $\mathbf{x}$ & $\mathbf{x}$ & - & . & . & \\
\hline Atolla vanhoeffeni & $\mathbf{x}$ & $\mathbf{x}$ & $\mathbf{x}$ & $\mathbf{x}$ & $\mathbf{x}$ & $\mathbf{x}$ & $\mathbf{x}$ & $\mathbf{x}$ & - & . & . & \\
\hline Atolla parva & $\mathbf{x}$ & $\mathbf{x}$ & $\mathbf{x}$ & $\mathbf{x}$ & $\mathbf{x}$ & $\mathbf{x}$ & $\mathbf{x}$ & $\mathbf{x}$ & . & . & . & \\
\hline Atolla wyvillei & $\mathbf{x}$ & $\mathbf{x}$ & $\mathbf{x}$ & $\mathbf{x}$ & $\mathbf{x}$ & $\mathbf{x}$ & $\mathbf{x}$ & $\mathbf{x}$ & . & . & . & \\
\hline Annatiara affinis & $\mathbf{x}$ & $\mathbf{x}$ & $\mathbf{x}$ & $\mathbf{x}$ & $\mathbf{x}$ & $\mathbf{x}$ & $\mathbf{x}$ & . & $\mathbf{x}$ & $\mathbf{x}$ & . & $\left.{ }^{* *}\right)$ \\
\hline Halicreas minimum & $\mathbf{x}$ & $\mathbf{x}$ & $\mathbf{x}$ & $\mathbf{x}$ & $\mathbf{x}$ & $\mathbf{x}$ & $\mathbf{x}$ & $\mathbf{x}$ & . & . & . & \\
\hline Pantachogon haeckeli & $\mathbf{x}$ & $\mathbf{x}$ & $\mathbf{x}$ & $\mathbf{x}$ & $\mathbf{x}$ & $\mathbf{x}$ & $\mathbf{x}$ & $\mathbf{x}$ & $\mathbf{x}$ & . & . & \\
\hline Colobonema sericeum & $\mathbf{x}$ & $\mathbf{x}$ & $\mathbf{x}$ & $\mathbf{x}$ & $\mathbf{x}$ & $\mathbf{x}$ & $\mathbf{x}$ & $\mathbf{x}$ & . & . & - & \\
\hline Rhopalonema velatum & $\mathbf{x}$ & $\mathbf{x}$ & $\mathbf{x}$ & $\mathbf{x}$ & $\mathbf{x}$ & $\mathbf{x}$ & $\mathbf{x}$ & . & . & $\mathbf{x}$ & . & \\
\hline Aegina citrea & $\mathbf{x}$ & $\mathbf{x}$ & $\mathbf{x}$ & $\mathbf{x}$ & $\mathbf{x}$ & $\mathbf{x}$ & $\mathbf{x}$ & $\mathbf{x}$ & $\mathbf{x}$ & . & . & \\
\hline Aeginura grimaldii & $\mathbf{x}$ & $\mathbf{x}$ & $\mathbf{x}$ & $\mathbf{x}$ & $\mathbf{x}$ & $\mathbf{x}$ & $\mathbf{x}$ & $\mathbf{x}$ & . & . & . & $\cdot$ \\
\hline Solmissus incisa & $\mathbf{x}$ & $\mathbf{x}$ & $\mathbf{x}$ & $\mathbf{x}$ & $\mathbf{x}$ & $\mathbf{x}$ & $\mathbf{x}$ & $\mathbf{x}$ & . & . & . & \\
\hline Haliscera bigelowi & $\mathbf{x}$ & $\mathbf{x}$ & $\mathbf{x}$ & $\mathbf{x}$ & $\mathbf{x}$ & $\mathbf{x}$ & . & . & . & $\mathbf{x}$ & . & $\left.{ }^{* *}\right)$ \\
\hline Crossota rufobrunnea & $\mathbf{x}$ & $\mathbf{x}$ & $\mathbf{x}$ & $\mathbf{x}$ & - & $\mathbf{x}$ & . & $\mathbf{x}$ & . & . & . & \\
\hline Aglantha digitale & $\mathbf{x}$ & $\mathbf{x}$ & $\mathbf{x}$ & $\mathbf{x}$ & $\mathbf{x}$ & . & $\mathbf{x}$ & . & . & $\mathbf{x}$ & $\mathbf{x}$ & $\left.{ }^{* *}\right)$ \\
\hline Chromatonema rubrum & $\mathbf{x}$ & $\mathbf{x}$ & $\mathbf{x}$ & $\mathbf{x}$ & . & . & . & $\mathbf{x}$ & . & . & . & \\
\hline Botrynema brucei & $\mathbf{x}$ & $\mathbf{x}$ & $\mathbf{x}$ & . & . & . & $\mathbf{x}$ & $\mathbf{x}$ & . & . & . & \\
\hline Pegantha laevis & $\mathbf{x}$ & . & $\mathbf{x}$ & $\mathbf{x}$ & . & $\mathbf{x}$ & . & . & $\mathbf{x}$ & . & . & \\
\hline Pegantha martagon & $\mathbf{x}$ & . & $\mathbf{x}$ & $\mathbf{x}$ & . & $\mathbf{x}$ & . & . & $x$ & . & . & \\
\hline Pegantha clara & . & $\mathbf{x}$ & $\mathbf{x}$ & $\mathbf{x}$ & $\mathbf{x}$ & $\mathbf{x}$ & $\mathbf{x}$ & . & $\mathbf{x}$ & . & . & \\
\hline Pelagia noctiluca & . & $\mathbf{x}$ & $\mathbf{x}$ & . & $\mathbf{x}$ & . & $\mathbf{x}$ & . & . & . & $\mathbf{x}$ & \\
\hline Amphogona apsteini & . & $\mathbf{x}$ & $\mathbf{x}$ & . & . & . & . & $\mathbf{x}$ & . & . & . & $* * * *)$ \\
\hline Nausithoe atlantica & $\mathbf{x}$ & . & . & $\mathbf{x}$ & . & . & $\mathbf{x}$ & $?$ & - & . & . & \\
\hline Pandea conica & $\mathbf{x}$ & . & . & $\mathbf{x}$ & . & $\mathbf{x}$ & . & . & $\mathbf{x}$ & . & $\mathbf{x}$ & \\
\hline Zygocanna vagans & $\mathbf{x}$ & . & . & $\mathbf{x}$ & $\mathbf{x}$ & . & . & . & . & . & $\mathbf{x}$ & \\
\hline Tima flavilabris & $\mathbf{x}$ & . & . & $\mathbf{x}$ & . & . & . & . & $\mathbf{x}$ & . & $\mathbf{x}$ & \\
\hline Halitrephes maasi & $\mathbf{x}$ & . & . & $\mathbf{x}$ & . & . & . & $\mathbf{x}$ & . & . & . & \\
\hline Bythotiara murrayi & $\mathbf{x}$ & . & . & . & . & . & . & . & . & ? & . & $\left.{ }^{* *}\right)$ \\
\hline Calycopsis gara & $\mathbf{x}$ & . & . & $\mathbf{x}$ & . & . & . & . & . & . & $\mathbf{x}$ & \\
\hline Paraphyllina ransoni & . & $\mathbf{x}$ & . & . & $\mathbf{x}$ & . & . & $\mathbf{x}$ & . & . & . & \\
\hline Crossota alba & . & $\mathbf{x}$ & . & . & . & . & . & . & . & $\mathbf{x}$ & . & $\left.{ }^{* *}\right)$ \\
\hline Amphogona apicata & . & $\mathbf{x}$ & . & . & $\mathbf{x}$ & . & $\mathbf{x}$ & $\mathbf{x}$ & . & . & . & \\
\hline Sminthea eurygaster & . & $\mathbf{x}$ & . & . & $\mathbf{x}$ & . & $\mathbf{x}$ & . & . & $?$ & . & $\left.{ }^{* *}\right)$ \\
\hline Sibogita geometrica & . & $\mathbf{x}$ & . & $\mathbf{x}$ & $\mathbf{x}$ & $\mathbf{x}$ & . & . & $\mathbf{x}$ & . & . & \\
\hline Solmaris flavescens & . & $\mathbf{x}$ & . & $\mathbf{x}$ & $\mathbf{x}$ & . & $\mathbf{x}$ & . & $\mathbf{x}$ & . & . & \\
\hline Bougainvillea platygaster & . & . & . & $\mathbf{x}$ & . & $\mathbf{x}$ & $\mathbf{x}$ & . & $\mathbf{x}$ & . & . & \\
\hline Pandea rubra & . & . & . & $\mathbf{x}$ & . & . & $\mathbf{x}$ & . & . & . & $\mathbf{x}$ & $* *)$ \\
\hline Geryonia proboscidalis & . & . & . & $\mathbf{x}$ & . & $\mathbf{x}$ & . & . & ? & . & . & \\
\hline Solmissus marshalli & . & . & . & $\mathbf{x}$ & $\mathbf{x}$ & . & $\mathbf{x}$ & . & . & . & $\mathbf{x}$ & $* * *)$ \\
\hline Pegantha rubiginosa & . & . & . & . & $\mathbf{x}$ & . & $\mathbf{x}$ & . & . & ? & . & \\
\hline Solmaris solmaris & . & . & . & . & $\mathbf{x}$ & . & $\mathbf{x}$ & . & $\mathbf{x}$ & . & . & \\
\hline Oceania armata & . & . & . & . & $\mathbf{x}$ & $\mathbf{x}$ & . & . & . & . & $\mathbf{x}$ & \\
\hline Cytaeis tetrastyla & . & . & . & . & . & $\mathbf{x}$ & $\mathbf{x}$ & . & . & . & $?$ & \\
\hline Deepstaria enigmatica & . & . & . & $\mathbf{x}$ & . & . & . & $\mathbf{x}$ & . & . & . & \\
\hline Neoturris pileata & . & . & . & $\mathbf{x}$ & . & . & . & . & ? & . & . & \\
\hline Cosmetira pilosella & . & . & . & $\mathbf{x}$ & . & . & . & . & $\mathbf{x}$ & . & . & \\
\hline Liriope tetraphylla & . & . & . & $\mathbf{x}$ & . & . & . & . & . & . & $\mathbf{x}$ & \\
\hline Aequorea tenuis & . & . & . & . & $\mathbf{x}$ & . & . & $?$ & . & . & . & \\
\hline Cunina duplicata & . & . & . & . & $\mathbf{x}$ & . & . & . & . & . & $?$ & \\
\hline Cunina frugifera & . & . & . & . & $\mathbf{x}$ & . & . & . & . & . & $?$ & \\
\hline Solmaris corona & . & . & . & . & $\mathbf{x}$ & . & . & $?$ & . & . & . & \\
\hline
\end{tabular}


Table II (contination)

\begin{tabular}{|c|c|c|c|c|c|c|c|c|c|c|c|c|}
\hline \multirow[t]{2}{*}{ Species } & \multicolumn{3}{|c|}{$>42^{\circ} \mathrm{N}$} & \multicolumn{4}{|c|}{$<42^{\circ} \mathrm{N}$} & \multicolumn{4}{|c|}{ Ecology } & \multirow[b]{2}{*}{$\left.{ }^{*}\right)$} \\
\hline & Sp & $\mathrm{Su}$ & $\mathrm{Au}$ & $\mathrm{Sp}$ & Su & $\mathrm{Au}$ & Wi & $\mathbf{B a}$ & $\mathrm{Di}$ & $\mathrm{Eu}$ & Ep & \\
\hline Porpita porpita & . & . & . & . & . & $\mathbf{x}$ & . & . & . & $\mathbf{x}$ & . & \\
\hline Cuvieria huxleyi & . & . & . & . & . & $\mathbf{x}$ & . & . & . & . & ? & \\
\hline Rhopalonema funerarium & . & . & . & . & . & . & $\mathbf{x}$ & . & . & $?$ & . & $\left.{ }^{* *}\right)$ \\
\hline Aglaura hemistoma & . & . & . & . & . & . & $\mathbf{x}$ & . & . & . & ? & \\
\hline Phialopsis diegensis & . & . & . & . & . & . & $\mathbf{x}$ & . & . & . & ? & \\
\hline Pegantha triloba & . & . & . & . & . & . & $\mathbf{x}$ & . & . & . & $?$ & \\
\hline Cunina peregrina & . & . & . & . & . & . & $\mathbf{x}$ & . & . & . & $\mathbf{x}$ & \\
\hline
\end{tabular}

$\left.{ }^{*}\right) \mathrm{Au}=$ autumn, $\mathrm{Ba}=$ bathy- and/or mesopelagic, $\mathrm{Di}=$ diurnal migrant, $\mathrm{Ep}=$ epipelagic, $\mathrm{Eu}=\mathrm{eurybathic}, \mathrm{Sp}=\mathrm{spring}$, $\mathrm{Su}=$ summer, $\mathrm{Wi}=$ winter. ${ }^{* *}$ ) According to Kramp these species are bathypelagic. ${ }^{* * *}$ ) According to Kramp this species is eurybathic. ${ }^{* * * *}$ ) According to Kramp this species is a surface form.

\section{REFERENCES}

References marked with ${ }^{*}$ are used to make the distribution maps.

*Arai, M. N. A. Brinkmann-Voss, 1980. Hydromedusae of British Columbia and Puget Sound. Can. Bull. Fish. aquat. Sci., 204: 1-192.

Baker, A. de C., M. R. Clarke \& M. J. Harris, 1973. The N.I.O. combination net (RMT $1+8$ ) and further developments of rectangular midwater trawls. J. mar. biol. Ass. U.K., 53 (1): 167-184, pls. I-II.

*Kramp, P. L., 1920. Anthomedusae and Leptomedusae from the "Michael Sars" North Atlantic Deep-Sea Expedition 1910. Rep. scient. Results Michael Sars N. Atlant. deep-sea Exped., 3 (2): 1-14.

,-- 1957 . Hydromedusae from the Discovery collection. Discovery Rep., 29: 1-128.

-, 1959 . The Hydromedusae of the Atlantic Ocean and adjacent waters. Dana Rep., 46: 1-283, pls. I-II.

*-_, 1965. The Hydromedusae of the Pacific and Indian Oceans. Dana Rep., 63: 1-162.

*-_, 1968. The Hydromedusae of the Pacific and Indian Oceans. Dana Rep., 72: 1-200.

MaAs, O., 1905. Die Craspedoten Medusen der SibogaExpedition. Siboga Exped., Monogr. 10 [6] (Livr. 26): [i-iii], 1-84, pls. I-XIV.

*Ramirez, F. C. M. O. Zamponi, 1981. Hydromedusae. In: D. Boltovskoy ed., Atlas del zooplancton del Atlantico Suboccidental: 443-469 (INIDEP, Mar del Plata).

Roe, H. S. L., A. de C. Baker, R. M. Carson, R. Wild * D. M. Shale, 1980. Behaviour of the Institute of Oceanographic Science's rectangular midwater trawls: Theoretical aspects and experimental observations. Mar. Biol., 56: 247-259.

*Roe, H. S. J., P. T. James * M. H. Thurson, 1984. The diurnal migrations and distributions within a mesopelagic community in the North East Atlantic, 6. Medusae, Ctenophores, Amphipods and Euphausiids. Progr. Oceanogr., 13: 425-460.

*Russell, F. S., 1953. The Medusae of the British Isles: 1-530 (Cambridge Univ. Press, Cambridge).

*Schmidt, H. E. \& J. Klinker, 1974. Hydromedusae (Coelenterata) from the Indian Ocean. "Meteor" Forsch. Ergebn., (D) 18: 29-38.

SPOEL, S. VAN DER, 1981. List of discrete depth samples and open net hauls of the Amsterdam Mid North Atlantic Plankton Expedition 1980 (project 101A). Bull. zoöl. Mus. Univ. Amsterdam, 8 (1): 1-10.

- , 1985. List of discrete depth samples and open net hauls of the Amsterdam Mid North Atlantic Plankton Expeditions 1982 and 1983 (project 101A). Bull. zoöl. Mus. Univ. Amsterdam, 10 (17): 129-152.

-, $1987 \mathrm{a}$. Medusae of the genera Paraphyllina, Periphylla and Atolla from the Amsterdam Mid North Atlantic Plankton Expeditions (1980-1983). Bijdr. Dierk., 57 (1): 42-52.

- 1 1987b. Annotated species list of the Mollusca, Tintinnida, Amphisolenia (Dinoflagellata) and Radiolaria collected in pump samples by the Amsterdam Mid North Atlantic Plankton Expeditions 19801983 (project 101A). Verslagen en technische gegevens, Inst. taxon. Zoöl. Amsterdam, 48: 1-99.

SPOEL, S. VAN DER \& J. BleEker, 1988. Medusae from the Banda Sea and Aru Sea plankton collected during the Snellius II Expedition. Indo-Malayan Zool., 5 (2): [in the press].

Spoel, S. van Der \& R. P. Heyman, 1983. A comparative atlas of zooplankton. Biological patterns in the oceans: 1-186 (Bunge, Utrecht).

Spoel, S. van der \& A. G. H. A. Meerding, 1983. List of discrete depth samples and open net hauls of the Amsterdam Mid North Atlantic Plankton Expedition 
1981 (project 101A). Bull. zoöl. Mus. Univ. Amsterdam, 9 (9): 77-91.

Utrecht, W. L. van, 1982. Some aspects of the distribution, metamorphosis and growth in Serrivomer parabeani Bertin, 1940 (Pisces, Apodes, Serrivomeridae) related to growth features in their otoliths. Beaufortia, 32 (7): 117-124.

*Vannucci, M. D. Navas, 1973. On the ecology of Indian Ocean Hydromedusae. Handbook int. Zoopl. Coll., 5: 1-54.
Winkler, J. TH., 1982. The Hydromedusae of the Amsterdam Mid North Atlantic Plankton Expedition, 1980 (Coelenterata, Hydrozoa). Beaufortia, 32 (3): 27-56.

Winkler, J. Th. R. W. M. van Soest, 1981. First record of the Scyphomedusa Deepstaria enigmatica Russell, 1967, from the mid North Atlantic Ocean (Coelenterata, Scyphozoa). Bull. zoöl. Mus. Univ. Amsterdam, 8 (4): 33-38. 